NBER WORKING PAPER SERIES

DE FACTO AND DE JURE PROPERTY RIGHTS:

LAND SETTLEMENT AND LAND CONFLICT ON THE AUSTRALIAN, BRAZILIAN AND U.S. FRONTIERS

\author{
Lee J. Alston \\ Edwyna Harris \\ Bernardo Mueller \\ Working Paper 15264 \\ http://www.nber.org/papers/w15264
}

NATIONAL BUREAU OF ECONOMIC RESEARCH

1050 Massachusetts Avenue

Cambridge, MA 02138

September 2009

\begin{abstract}
For comments we thank Eric Alston, Lee Cronk, Ernesto Dal Bó, John Ferejohn, Stephen Haber, P.J. Hill, Gary Libecap, Henry Smith, Ian Wills and participants at: a seminar on social norms at the Institute for Advanced Study in Princeton; a conference on "Australian Economic History in the Long Run;" the Research Group on Political Institutions and Economic Policy held at Princeton University; and a seminar at Monash University. Alston and Mueller acknowledge the support of NSF grant \#528146. Alston thanks the STEP Program at the Woodrow Wilson School at Princeton for their support as a Visiting Research Scholar during 2008/2009 and The Australian National University for support as Research Fellow in 2009. We thank Eric Alston for research assistance. The views expressed herein are those of the author(s) and do not necessarily reflect the views of the National Bureau of Economic Research.
\end{abstract}

NBER working papers are circulated for discussion and comment purposes. They have not been peerreviewed or been subject to the review by the NBER Board of Directors that accompanies official NBER publications.

(C) 2009 by Lee J. Alston, Edwyna Harris, and Bernardo Mueller. All rights reserved. Short sections of text, not to exceed two paragraphs, may be quoted without explicit permission provided that full credit, including $\odot$ notice, is given to the source. 
De Facto and De Jure Property Rights: Land Settlement and Land Conflict on the Australian, Brazilian and U.S. Frontiers

Lee J. Alston, Edwyna Harris, and Bernardo Mueller

NBER Working Paper No. 15264

August 2009

JEL No. D72,Q15,N40,N50,O17,K11

\begin{abstract}
We present a conceptual framework to better understand the interaction between settlement and the emergence of de facto property rights on frontiers prior to governments establishing and enforcing de jure property rights. In this framework, potential rents associated with more exclusivity drives "demand" for commons arrangements but demand is not a sufficient explanation; norms and politics matter. At some point enhanced scarcity will drive demand for more exclusivity beyond which can be sustained with commons arrangements. Claimants will therefore petition government for de jure property rights to their claims - formal titles. Land conflict will be minimal when governments supply property rights to first possessors. But, governments may not allocate de jure rights to these claimants because they face differing political constituencies. Moreover, governments may assign de jure rights but be unwilling to enforce the right. This generates potential or actual conflict over land depending on the violence potentials of de facto and de jure claimants. We examine land settlement and conflict on the frontiers of Australia, the U.S. and Brazil. We are interested in examining the emergence, sustainability, and collapse of commons arrangements in specific historical contexts. Our analysis indicates the emergence of de facto property rights arrangements will be relatively peaceful where claimants have reasons to organize collectively (Australia and the U.S.). The settlement process will be more prone to conflict when fewer collective activities are required. Consequently, claimants resort to periodic violent self-enforcement or third party enforcement (Brazil). In all three cases the movement from de facto to de jure property rights led to potential or actual conflict because of insufficient government enforcement.
\end{abstract}

Lee J. Alston

Program on Environment and Society

Institute of Behavioral Science

Department of Economics

University of Colorado at Boulder

Boulder, CO 80309-0483

and NBER

Lee.Alston@colorado.edu

Edwyna Harris

Monash University

Edwyna.Harris@BusEco.monash.edu.au
Bernardo Mueller

University of Brasilia

bmueller@unb.br 


\section{De Facto and De Jure Property Rights: Land Settlement and Land Conflict on the Australian, Brazilian and U.S. Frontiers}

\section{Introduction}

Australia, Brazil and the U.S. are all physically large countries and each had different patterns of land settlement on their frontiers. We define the frontier as land that is too far from the central government such that the initial enforcement of property rights by government is prohibitively expensive. We examine the way in which the extant specified property rights in each country affected settlement and in particular the potential and emergence of subsequent land conflict. Property rights, along with relative prices, provide the incentive for settlement and conflict on frontier lands. Property rights can be either de facto or de jure. By de facto we mean that the property rights are specified by first person (an individual claims the land) or second person (a group assigns rights or norms emerge) while de jure rights are specified by a government with recognized authority. Both de facto and de jure rights may be enforced by first person (self-enforcement); second person (norms or rules of a group, club or association) or third party (private militias or government). When land is relatively abundant, informal de facto property rights may arise to limit dissipation, entice entrants, and yet avoid conflict. As land becomes scarcer, settlers have the incentive to form a commons arrangement to exclude outsiders and thereby limit the potential dissipation from the resource. As entrants become increasingly heterogeneous with respect to endowments, de facto commons arrangements may not suffice to limit dissipation, and claimants have an incentive to lobby the government to turn their de facto claims into de jure property rights with government enforcement. But, the economic rents may not be sufficient for property rights to emerge because political rents may vary from the economic rents.

Because of competing demands for de jure rights by heterogeneous claimants, governments may opt not to legitimate the de facto claims of the initial entrants yet they may not enforce the specified de jure rights of alternative claimants. We found that the greater the time between the specification of de jure property rights and their enforcement the greater the potential for rent dissipation, particularly violence between those holding and enforcing de facto rights and those with specified but not enforced de jure rights. The determinants of the specification and enforcement of de jure property rights depends on the political power of the competing claimants. Where the political power of incumbents is high (Brazil) de jure rights will tend to support the de facto rights. Alternatively, where political power is mixed (Australia and the U.S.) the specification and enforcement of de jure rights may not coincide. Incumbents may retain de facto rights because of little enforcement by the government, but incur costs to prevent the de jure right holders from exercising their specified rights. 
The ability to retain de facto rights in the face of someone else holding the de jure rights rests on political, wealth and violence advantages for the "first possessor" (home court advantage).

In Section II we first present a matrix showing the possible combinations of property rights which highlights the roles played by economic rents, norms and politics. Following this we present a demand driven framework for the initial settlement of the frontier which by definition entails settlement with de facto rights either self-enforced or second-party enforced. The framework highlights the likelihood for conflict over property rights as rents increase. Conflict dissipates some of the rents of settlement and frequently leads to a demand for de jure property rights. After a discussion of our demand framework we develop some hypotheses about the political supply of the specification and enforcement of rights. In subsequent sections we use concepts about economic rent, norms and politics to analyze the settlement of three frontiers in the $19^{\text {th }}$ century along with the potential and realization of land conflict over property rights. The frontiers include Eastern Australia (New South Wales and Victoria), the arid Great Plains region of the U.S., and the emerging coffee frontier in Brazil. We are interested in examining the emergence, sustainability, and collapse of de facto arrangements as well as the ultimate specification and enforcement of de jure property rights.

\section{Property Rights and Land Settlement}

Property rights affect the timing of settlement as well as the use of land. A full set of property rights includes the following: 1) the right to use the asset in any manner that the user wishes, generally with the caveat that such use does not interfere with someone else's property right; 2) the right to exclude others from the use of the asset; 3 ) the right to derive income from the asset; 4) the right to sell the asset; and 5) the right to bequeath the asset to someone of your choice. If one possesses the full set of property rights, resources will be utilized optimally. But, a full set of property rights never exists because there are some margins of use that are too costly to specify and enforce as Ronald Coase (1960) noted years ago: "sometimes it costs too much to put the matter right." As a result some attributes may be either de jure or de facto left as open access. ${ }^{1}$ Individuals and groups have incentives to expropriate use rights over attributes that the state leaves as open access. For land settlement this could lead to different types of behavior which can dissipate the rental value of the land. If land is open to squatting on the basis of first possession then people will dissipate some resources in the race to claim land (Anderson and Hill 1990). If land is left in open access, this may lead to overuse of the land in the familiar problem of the "tragedy of the commons," unless rules about use become specified and enforced. Furthermore, unless occupants of land have a formal title to their land, along with the

\footnotetext{
${ }^{1}$ Barzel (1989) makes this point most explicitly and clearly.
} 
enforcement by the state, occupants will expend resources defending their claim. In the absence of formal specification and enforcement of titles to land, individuals will have an incentive to reach collective agreements to prevent trespass from outsiders as well as expend individual resources to demarcate and defend claims.

We illustrate the six possible arrangements of property rights in Table 1 where the columns vary according to who specifies the property rights and the rows vary by who enforces the rights. On both dimensions the possible actors are first person (the claimant), second party (a group of claimants collectively) or third party (government or e.g. gunmen). First party specification and enforcement, the top left cell in Table 1, occurs when scarcity is low. An individual moves to the frontier and claims land. The person typically demarcates his claim in some fashion and because scarcity is low there is little threat of his keeping the land. As other claimants move to the frontier the potential for rent dissipation increases and enforcement may be transferred either to a second or third party. Enforcement by a second party occurs when norms develop such that new entrants respect existing claims. These norms are generally based on a shared cultural endowment within a small group. In this case, there is first party specification but second party enforcement (first column, second row of Table 1). This arrangement may be sufficient to limit rent dissipation and violence during the early stages of migration to the frontier because land scarcity is relatively low.

Table 1

\begin{tabular}{|c|c|c|c|}
\hline \multicolumn{4}{|c|}{ Specification of Property Rights } \\
\hline \multirow{3}{*}{ 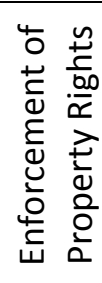 } & $\begin{array}{l}1^{\text {st }} \text { Person Specification } \\
1^{\text {st }} \text { Person Enforcement }\end{array}$ & $\begin{array}{l}2^{\text {nd }} \text { Party Specification } \\
1^{\text {st }} \text { Person Enforcement }\end{array}$ & $\begin{array}{l}3^{\text {rd }} \text { Party Specification } \\
1^{\text {st }} \text { Person Enforcement }\end{array}$ \\
\hline & $\begin{array}{l}1^{\text {st }} \text { Person Specification } \\
2^{\text {nd }} \text { Party Enforcement }\end{array}$ & $\begin{array}{l}2^{\text {nd }} \text { Party Specification } \\
2^{\text {nd }} \text { Party Enforcement }\end{array}$ & $\begin{array}{l}3^{\text {rd }} \text { Party Specification } \\
2^{\text {nd }} \text { Party Enforcement }\end{array}$ \\
\hline & $\begin{array}{l}1^{\text {st }} \text { Person Specification } \\
3^{\text {rd }} \text { Party Enforcement }\end{array}$ & $\begin{array}{l}2^{\text {nd }} \text { Party Specification } \\
3^{\text {rd }} \text { Party Enforcement }\end{array}$ & $\begin{array}{l}3^{\text {rd }} \text { Party Specification } \\
3^{\text {rd }} \text { Party Enforcement }\end{array}$ \\
\hline
\end{tabular}

Where norms do not evolve or are not sufficient to deter encroachment, second party enforcement may be replaced with third party enforcement of de facto rights (first column, bottom row of Table 1). At this point, incumbents will hire agents or use local government to enforce their claims. ${ }^{2}$ Settlers may employ third parties, who take on the role of a private militia or police force creating a violence advantage over new comers. Employing agents to enforce member claims is beneficial when individuals claim large areas reducing their ability to police and defend these claims. Agents may utilize violence to

\footnotetext{
${ }^{2}$ We will discuss in more detail later the advantages of the first possessors, one of which is the capture of local governments. We will later refer to the advantages as the "home court" advantage.
} 
defend their employers' claims against entrants. Alternatively, individuals may rely on local government to enforce claims even though specification of de jure rights do not exist or are not in the hands of the government enforcer. All three cells in the first column indicate that the claimant(s) established de facto property rights. However, formal commons arrangements that is, the creation of clubs or associations is absent. For clubs or associations to form either norms must be very strong or the returns to an individual from the collective must be sufficiently high to rise above the familiar free rider problem.

As competition for land increases with the number of new arrivals at the frontier there may be a shift away from first to second party specification. Second party specification leads to the creation of commons arrangements such as, clubs or associations. Formation of clubs or associations is more likely when groups are small, homogenous, geographically proximate, and shared norms exist. Once formed enforcement of the club's claims may be undertaken by either the first, second, or third party; these arrangements correspond to the cells in the middle column of Table 1. Exactly who bears the costs of enforcement once de facto property rights have been established is determined by the interplay of economics, norms and politics. In some instances, column 2, row 1, clubs define rights but there is still self-enforcement. This is a situation where claimants all gain legitimacy from the club and do not intrude on each other but the defense against outsiders remains in the hands of the individual claimant. A more general outcome is de facto (commons) specification and enforcement- column 2, row 2 . For this reason, one advantage of creating a formal commons is to spread defense costs across a group of individuals all of whom incur a smaller marginal cost than if they undertook defense individually. In addition to defense from outsiders, e.g. aboriginals or exclusion of new entrants, there may be other collective benefits from specification and enforcement in the same hands. If the land is used in common, then rules about use will limit the dissipation of rents from overstocking. The benefits from organization are greater for specification and enforcement if there are additional collective goods provided by the commons for which there exist economies of scale.

In the absence of exogenous shocks, second party specification and enforcement may remain stable over a long period. However, there may be a point at which second party enforcement is no longer sufficient to prevent encroachment. For example, legislative changes may induce competition for land, increasing the costs of collective defense. At this point, the club may find it cost effective to hire third party enforcement or, local governments may enforce the rights of the commons even though they did not define the rights. Much like the case where there is first party specification and third party enforcement, employing agents to enforce member claims is beneficial when the geographical area of 
defense is large compared with member numbers. Alternatively, the club may rely on government to enforce member claims even though de jure rights are absent. In this case, local officials enforce de facto land claims either because club members are local officials or because government officials can obtain economic and/or political rents from the club. In some instances the association may offer monetary compensation for government enforcement by paying bribes. Assuming some degree of democracy exists, political rents are the currency the club can offer local officials in return for enforcement, specifically votes or campaign contributions.

Column 3 contains the cells for the specification of de jure rights, which by definition means specification by the authorized government. Government specification often takes place after the creation of de facto rights and it is at this point that de jure rights can either recognize the de facto claimants or undermine the existing de facto rights. Governments may choose to define but not enforce de jure rights - column 3, rows 1 and 2 . As with earlier rights structures, economics, norms and politics may play varying roles over time and space. For example, with an extended suffrage, politicians may assign property rights to redistribute land away from the de facto claimants, who may have the highest economic return. Further, if de jure rights do not support the prevailing de facto allocation the government will increase the potential for conflict if they choose not to enforce the de jure rights - rows 1 and 2. Government specification and first party enforcement means that individuals must defend their de jure rights against others. In this case, the costs of defense may outweigh the benefits of the de jure rights, therefore individuals will opt against migration to the frontier. This will lower the likelihood of conflict between newcomers and incumbents by limiting competition. Government specification and second party enforcement (middle cell, bottom row of Table 1) exists when the government allocates de jure rights but enforcement takes place via a commons arrangement. Enforcement by a commons arrangement may emerge where governments either lack sufficient resources to enforce claims or choose not enforce de jure rights for political reasons. If clubs did not previously exist prior to government specification, they may be formed at this point with their sole purpose being to defend the rights of extant claimants against encroachment. The final and most complete category of de jure rights is where there is government specification and enforcement of property rights. Here the government allocates and enforces rights, reducing the potential for conflict because we assume that governments have a comparative advantage in violence. ${ }^{3}$

\footnotetext{
${ }^{3}$ This assumption flows from numerous accounts of the role of the state in preventing the dissipation of rents. For recent treatments see Acemoglu and Robinson (2006) and North, Wallis and Weingast (2009).
} 
As discussed earlier economic rents, political rents and norms all play roles in the specification and enforcement of property rights. To better understand the roles played by each we will first present a "demand" driven framework for the emergence of property rights. The core of the framework is that economic rents drive the determination of property rights. We illustrate in Figure 1 the "demand" for more secure property rights as a function of its scarcity value. In Figure 1 the horizontal axis measures the relative scarcity of a given resource (from right to left) and the vertical axis measures the net present value that accrues to the claimant of that resource. ${ }^{4}$ The line segment $A B C D E$ shows that the net present value of the resource decreases as it becomes less scarce. We assume that the line segment $A B C D E$ represents the highest return from using the resource with varying amounts of capital or labor.

Figure 1- The Demand for and Evolution of Property Rights

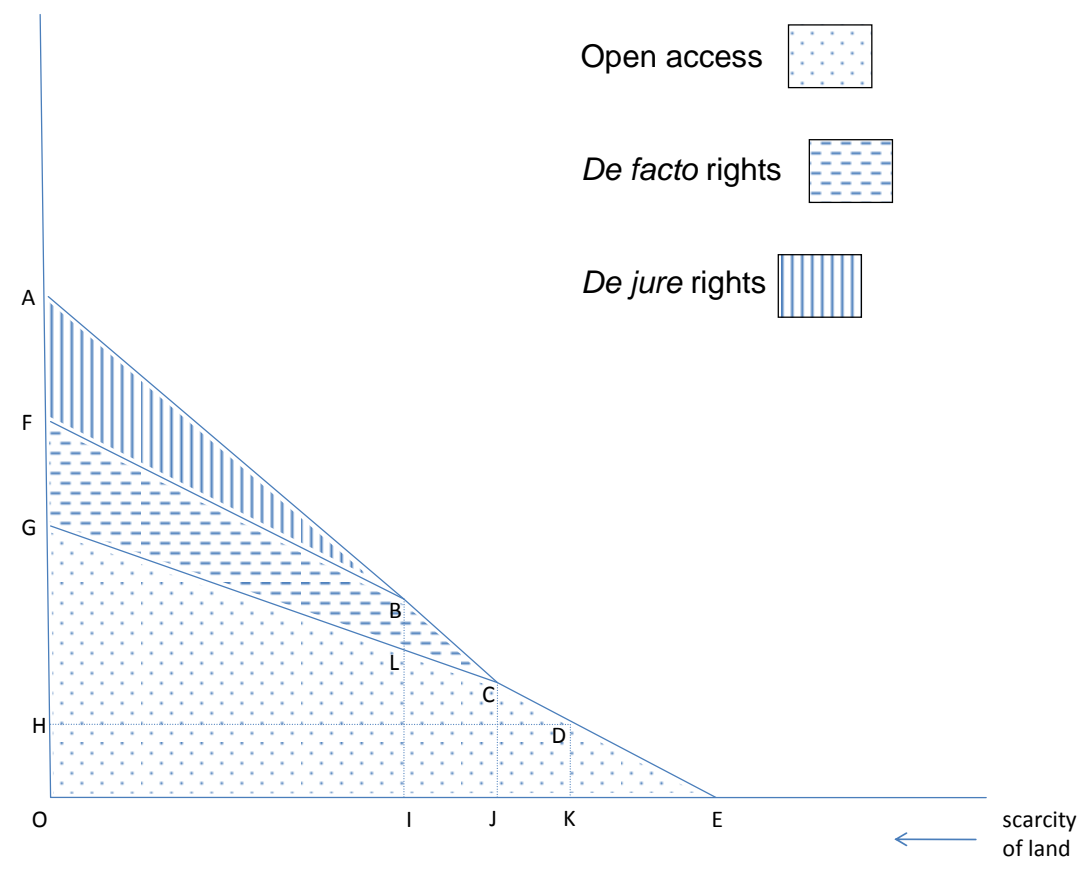

The returns from land use given relative prices may be greater for relatively capital intensive activities e.g., cattle ranching or more labor intensive activities, e.g., pre-mechanized agriculture. In the case of land the measure of scarcity value could be the distance of a plot of land to a market center, as transportation costs are often the main determinant of land value. At point $E$ land is so far from the market center or so abundant that the economic return is zero. The segment GLCDE represents the net

\footnotetext{
${ }^{4}$ We expand on the framework developed in Alston, Harris and Mueller (forthcoming); Alston, Libecap and Schneider (1996) and Alston, Libecap and Mueller (1999).
} 
present value of land under an open access arrangement. $\mathrm{OH}$ represents the opportunity cost of the settlers with the lowest opportunity cost, given the costs of settling on the frontier.

Settling on the frontier will vary considerably with climatic conditions. For example, the fixed costs of migrating and sustaining a subsistence standard of living are lower in tropical regions than in colder climates, where settlers may have to wait a year to plant and harvest crops. In Figure 1 , point $K$ represents the economic frontier where it becomes worthwhile for a settler to migrate to the frontier. ${ }^{5}$ At points between $J$ and $K$ open access conditions prevail which means that property rights are not formally defined or enforced, but this does not affect the return to the resource given that it is still abundant relative to the competition for it. Though land is abundant, migrants may find it worthwhile to establish norms pertaining to the amount of land claimed. ${ }^{6}$ This appears relatively easy to do because initially the settlers are relatively homogeneous with respect to their opportunity costs and typically other socio-economic endowments. In terms of our taxonomy this would be second party specification and first person enforcement.

As the net present value increases, e.g. because of lower transportation costs or higher prices for the output of the land - represented here as the upward sloping line segment CD as one moves leftward from $K$ - new users arrive, yet they are able to get access to the resource without detracting much from the use of those who were already there. At distance IJ resource users still tend to be relatively homogenous, but the return from an open access resource - ILCJ - is lower than moving to a more limited commons - IBCJ- one in which new entry is restricted. The relatively higher return from a commons arrangement excluding outsiders creates the demand for informal property rights, which are sufficient to mitigate the otherwise existing dissipation of the rental stream. It is easier for homogeneous users to reach agreements concerning exclusivity for two reasons: 1 ) the claimants generally share similar cultural norms (endowments); and 2) in some instances there is a common collective good that will bring people together to reach agreements. With a common cultural background, potential disputes are easily defused as social pressure along with the incentive to cooperate yields higher expected returns than confrontation. The most obvious collective good is common defense to prevent encroachments from potential claimants. Squatting prevails yet the

\footnotetext{
${ }^{5}$ In our figure, distance is the frontier but it could as easily be the quality of soil. Our framework of "rents" determining arrival times on the frontier under open access conditions is an endowments explanation but for both commons arrangements to emerge as well as formal rights, norms or politics will matter.

${ }^{6}$ We recognize that this assumes that norms are driven partially driven by rents.
} 
absence of government-enforced private property rights does not pose significant costs. ${ }^{7}$ The wedge $B L C$ is the marginal return from switching from open access with limited norm specification to collective or commons arrangements for land in region IJ. In our taxonomy this is a movement from second party (norm) specification with self-enforcement to second party specification and enforcement. There is a gain to having a commons arrangement consisting of de facto property rights, as opposed to open access, but not yet for having formally defined property rights. That is, the level of competition for land is sufficiently high that open access would lead to losses, but not sufficiently high for formal property rights to be an improvement over commons arrangements.

For land in the region $\mathrm{Ol}$, closer to the market center, NPVs are higher, and the informal institutions that developed can no longer cope with the increased competition for the resource. It becomes necessary to expend effort, time and money to assure continued possession of the resource and the income derived from it. This may involve incurring costs to exclude others or the cost from suboptimal uses. It may also include the costs to lobbying for changes from de facto to de jure property rights. At some point it becomes beneficial in the aggregate to have officially defined and enforced de jure property rights. The increased value that would result from formally defined and enforced de jure property rights is the pie-shaped area $A B F$ which represents the increased value of land versus the next best commons arrangement for property rights. $A B F$ is the potential rent that forms the basis for the demand for de jure property rights. In our taxonomy this would be a movement from second party specification and enforcement to third party specification and enforcement. Nevertheless, the movement from a commons arrangement to de jure property rights entails redistribution which in turn generates the potential for conflict, an issue we return to later.

Many of the early studies on the evolution of property rights simply assumed that as the area $A B F$ became sufficiently large de jure property rights would emerge. This notion has been termed the naïve theory of property rights, as it does not analyze the collective action problems or the politics that determine the supply of formal property rights (Eggertsson, 1990:250). In order to bring into the analysis the supply of property rights we extend our model so as to explicitly incorporate the fact that competing types of settlers with a different set of endowments typically arrive at different times at the frontier. ${ }^{8}$ In our case studies these different groups are, in order of arrival; ranchers versus homesteaders for the US;

\footnotetext{
${ }^{7}$ See Anderson and Hill (2002); Eggertsson (1990); Ostrom (1990); and (2009); and Umbeck (1981) for accounts of local groups allocating resources under "common" arrangements. See Smith (2000) for an analysis of "semicommons" arrangements.

${ }^{8}$ Libecap (2007) stresses this point.
} 
squatters versus selectors in Australia; and large coffee plantation owners with slaves versus smallholders in Brazil. By focusing on the different endowments of the competing groups we can analyze the disputes that arise over land and make inferences about how these differing endowments affect the political outcome that ultimately decides the form of the property rights that will emerge.

As stated in our initial discussion of Figure 1 the NPV from land may vary by whether the land is put into cattle or agriculture. Relatively abundant capital versus labor endowed claimants may face separate NPV schedules due to different access to inputs required to make the land productive, such as capital, technology or experience. Once we incorporate different payoffs from using the land, it becomes possible for the first entrant to have higher opportunity costs than the subsequent arrivals, for example in the US where capital (ranchers) preceded labor (homesteaders), or in Australia where the early squatters preceded selectors, and in Brazil where large coffee plantation owners preceded smallholders. These situations are depicted in Figure 2 where two sets of NPVs are superimposed. The set with higher NPVs for land in a given region is marked with capital letters and, to simplify the exposition, will be referred to as 'capital' whereas the lower set, with non-capitalized letters, will be referred to as 'labor'.

As drawn in Figure 2 capital arrives at the frontier at $\mathrm{K}$ prior to labor which arrives at $\mathrm{k}$, despite the fact that capital's opportunity cost is higher than labor's, $\mathrm{OH}>\mathrm{O}$. Naturally different relative opportunity costs and NPVs could lead to labor arriving first. ${ }^{9}$ Whatever the case, the asynchronous nature of arrival allows one group to establish and entrench itself on the land, possibly for a long period of time. When the second type of claimant arrives the NPV curves of the incumbent adjust themselves to reflect the increased competition. This adjustment would typically involve three movements; (i) an overall decrease of the NPV at each point; (ii) an increase of the area of the wedges that represent the gains to having de facto commons arrangements versus open access as well as the gains from de jure property rights over commons arrangements; and (iii) a rightward shift of points $J$ and $I$ with de facto commons arrangements and de jure property rights becoming desirable earlier given the presence of a new entrant. The curves of the entrant already reflect in "Cournot" fashion the NPVs that take into account the incumbent's presence.

\footnotetext{
${ }^{9}$ As drawn the figure implies that one type of claimant would always be able to make more productive use of the land at each distance for a given type of property rights, implying that in order to achieve efficiency the most valued user should retain the use rights and ultimately the government should allocate property rights to the highest valued user. However, it can very well be the case that one use of the land, such as ranching, is more productive in a frontier situation (towards the right of the graph) and another type of use, e.g. agriculture, is more productive once the frontier has evolved (towards the left). In this case inefficient land use would arise if i) secure property rights - though these may be informal -were not in place to facilitate the transfer of the land to its higher user, or ii) users are unable to quickly change their use of the land, i.e. ranchers becoming farmers.
} 
If we consider Figure 2 to represent the situation after the adjustment of the incumbent's payoffs to the threat of entrant's arrival, we see that to the left of point $k$ both types will find it in their interest to be on the land. The more to the left, that is, the higher the return to the use of the land, the greater will be the competition among the groups. The greater this competition the greater will be the incentive for commons arrangements to emerge and the greater will be the demand for de facto and later de jure property rights.

Figure 2 - The demand for property rights with competing claimants.

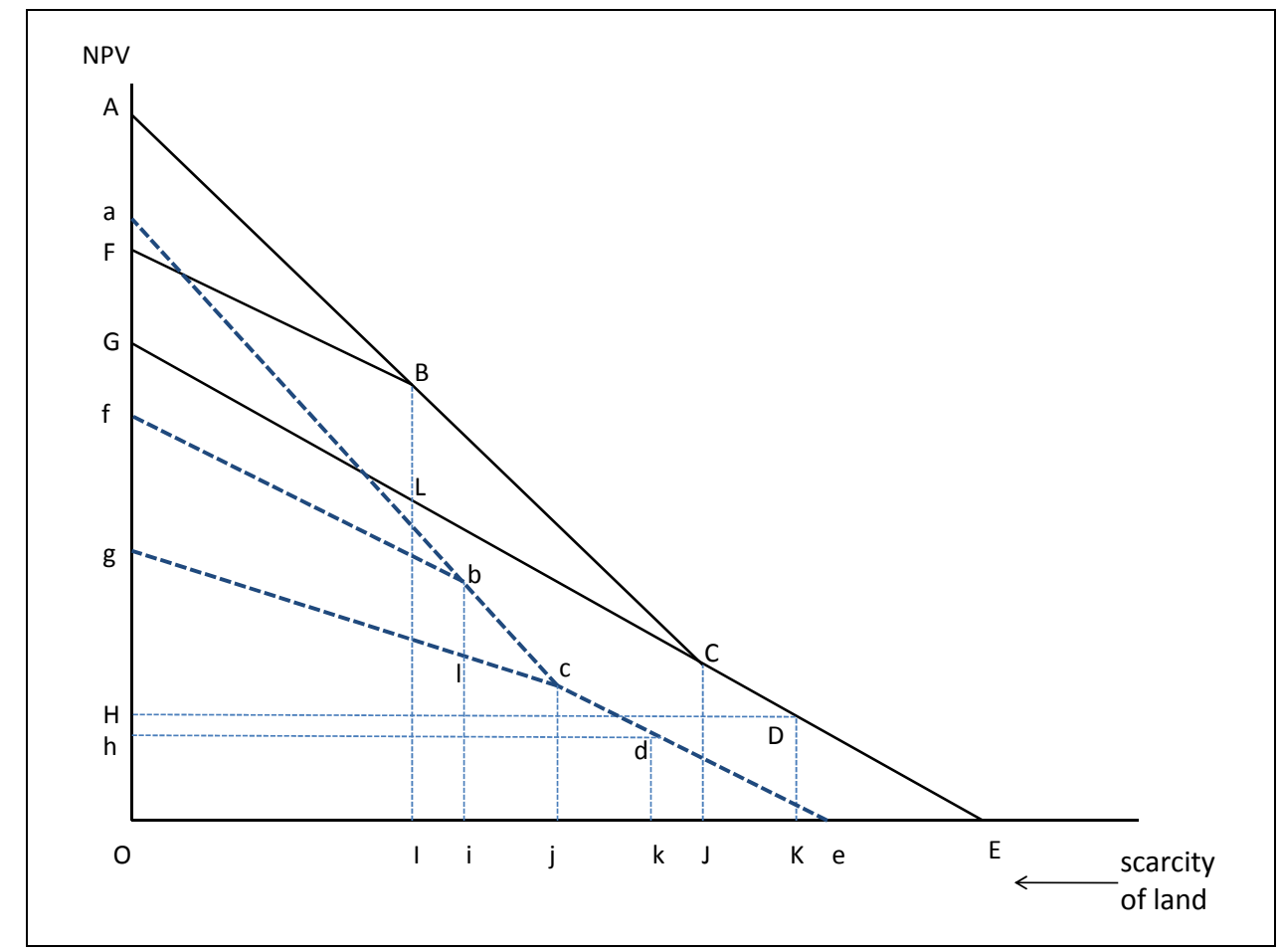

Initially de jure property rights will be non-existent, but as value increases, the potential "rents' will be an incentive for the government with authority to act which may: sustain the incumbent's de facto rights; redistribute the specification and enforcement of de jure rights towards the entrant; or any myriad intermediate combinations, the most common of which appears to be specification without enforcement. Clearly the outcome depends on the result of politics, which involves not only the incumbent and the entrant, but also local and the central governments, including their voters and constituencies.

The question that arises is whether anything can be said about the determinants of the supply response by governments. Though we cannot predict specific outcomes, we can discuss the characteristics of the claimants along with the political institutions in place both of which affect the 
supply of property rights. ${ }^{10}$ Once the new entrant has arrived on the frontier there is the potential for dispute and conflict. This dispute plays out both physically, in loco, as well as politically. It is almost tautological that ceteris paribus the greater the relative capabilities for violence of one group over the other, the greater the probability that the emergent de facto property rights will favor that group. But this prediction can become more precise if we note that the sequential nature of the groups' arrivals implies that the early entrant will have a "home court" advantage as it is often easier to defend than to usurp. ${ }^{11}$ This advantage is particularly significant in the situation portrayed in Figure 2 where the incumbent was drawn to the frontier by high benefits rather than by low opportunity costs. In addition there may be further rents that the incumbents capture through information gathered over time by being on the land. These benefits translate into economic and potentially political clout that enhances the home court advantage. Thus the greater the head start of the incumbent, that is, the time between $K$ and $k$, and the greater the incumbent's NPV in that period, the greater the likelihood that the incumbent will retain de facto property rights. The "home court" advantage should also help in the political allocation of rights which the incumbent would demand at distance $J$ and the entrant at distance j. Importantly, which will become clear in our case studies the specification of de jure rights may be part of the NPV of the entrant. The home court advantage translates into more resources to lobby for de jure property rights by the incumbent compared to the entrant as well as lobbying for a lack of enforcement of de jure rights in the case that this caused new entrants. But, lobbying is not the sole factor determining the government's specification and enforcement of property rights.

Another important characteristic of the competing claimants for determining the supply of property rights is the relative size of the gains from having de jure property rights, versus losing completely to the other claimant. In other words, the claimants would be willing to expend everything above their opportunity cost to secure the right though in principle one would only need to expend an amount greater than the alternative claimant. For the "capitalist" he would be willing to expend area $H A B C D$ and

\footnotetext{
${ }^{10}$ The degree of suffrage appears to be an important determinant in our case studies.

${ }^{11}$ Smith (2002: S482) argues: "In common-pool arrangements regimes, exclusion seems to be basic in the sense that efforts at exclusion are the first methods used to define property in a resource. The evidence from English land use is consistent with early exclusion." Smith (2002) gives numerous other examples consistent with current "rights" holders using exclusion successfully to deter entrants. Acheson's (1979 and 1988) discussion of the use of exclusion amongst lobster fishermen is a particularly good example consistent with "home court" advantage. Smith (2002: S485) also makes the excellent observation that in deciding between governance and exclusion as mechanisms for controlling behavior on the commons that "a limit on behavior is pointless unless access is limited first."
} 
for labor, she would be willing to expend habcd. ${ }^{12}$ These areas measure the rents over opportunity cost from getting effective de jure property rights for each group assuming all entrants within a group have the same opportunity cost. To the extent that opportunity costs increase for later entrants then the willingness to pay would be less. In the political world the amount that they would need to pay most likely would be substantially less because of only needing a winning coalition. It is not the case that we can simply compare both values and infer that the one with the larger gains will prevail as the outcome depends as well on other circumstances such as the preferences of the actors involved in the political process. Nevertheless, we can infer that for any given political process, the differences in the relative gains to each group will increase their willingness to invest in lobbying and increase the probability of a favorable outcome to that group ${ }^{13}$ - though the outcome for the capitalist may simply be a lack of government enforcement of the extant de jure specified rights of the new entrant.

The distribution of the gains from secure formal property rights among the members of the same group may also be a characteristic with important consequences for the property rights that get supplied. Note that in Figure 2 these gains are triangle-shaped ( $A B F$ and $a b f$ ), implying that some members of the group receive greater gains from secure private rights than others. One could imagine a situation in which that area would be closer to a rectangle with most members receiving similar gains. Under such circumstances the collective action which is crucial for mounting the demand for property rights may be easier to achieve than in the case where the intragroup heterogeneity is larger. ${ }^{14}$ Groups with better collective action will, ceteris paribus, have higher probabilities of being favored by the political process.

Lobbying by special interest groups matter but politicians also have to pay heed to the preferences of voters, particularly if the issue is salient and suffrage is universal. Given the centrality of land to production, especially in agricultural and pastoral economies, the property rights to land are an important issue in the utility function of individuals. If the franchise is widely held, e.g. all adult males regardless of land ownership, then we would expect to see the property rights to land favor the small holder.

\footnotetext{
${ }^{12}$ For the "capitalist" some rents may be used to prevent the enforcement of the de jure rights of labor endowed claimants whereas for the labor endowed claimants some rents may be expended to have their de jure rights enforced.

${ }^{13}$ See Appendix I for a formalization of this result.

${ }^{14}$ Ostrom (2009) has argued that in some situations heterogeneity may be beneficial in overcoming the collective action problem of organization. This is also well-know in cartel literature in IO; if there is a member who disproportionately would win from collective action, this player would incur the costs of organizing and sustaining the commons arrangement.
} 
Finally, we can make inferences regarding the outcomes of the political process by considering even some very general characteristics of that process. The preferences of the central government are naturally key determinants of the outcome. Whether those preferences support the incumbent or the entrant is an important factor, but by no means the sole determinant of the outcome. Where political support favors the first arrival this adds to the "home court" advantage and greatly increases the probability that the early arrivals will stay on the land, to a point where de jure property rights might not even strictly be necessary as de facto rights are bolstered by both political and physical strength. It is even possible, as we shall see in the Brazilian case, that this situation evolves with the incumbents (large coffee planters) effectively taking over the government. Where the political support at the center supports the newer entrant the final outcome still depends on other factors, such as the size of the "home court" advantage. If the support provided by the central authority is enough to overcome the resistance of the incumbent we will see the specification of de jure property rights transferring rights from the incumbent to the entrant. But, in many instances the political will is sufficient to change the de jure rights but not enough to implement the enforcement of de jure property rights. As such de facto rights may determine resource use for a long time, a situation we shall see that prevailed in our U.S. case study for over 50 years. The disjuncture between the specification and enforcement of rights in many instances appears to be the result of the specification being in the hands of a central government while the enforcement is in hands of a local government which is captured by the earlier wealthier arrivals.

In the next three sections we analyze the process of the emergence and evolution of property rights for land on the frontiers in Australia, the U.S. and Brazil, using the taxonomy and framework above as guides for the analysis. In all three cases there is an early entrant that is challenged by a subsequent entrant or potential entrant. In the Australian and U.S. cases commons arrangements emerge to reduce dissipation within entry groups whereas in Brazil self-enforcement/third party enforcement limited dissipation with some collective lobbying later in the political arena. Over time potential or actual disputes arise between entrant groups and there is a demand by claimants for de jure property rights to reduce the rent dissipation that emerges from those disputes. This demand is eventually met with a supply of de jure property rights which in all three cases involves the central government as the key player and indirectly the interests they represent, which in some cases are the direct contenders and in other cases more diffuse constituencies such as voters. In each case we show how the characteristics of the players, the markets that determine the NPVs, and the nature of the political process determine the property rights that emerge. 


\section{Settlement of the Australian frontier}

Settlement of the Australian frontier began in the late 1820 s. Prior to 1820 , population was concentrated around the original convict settlement at Botany Bay, New South Wales (NSW). NSW was the sole jurisdiction in eastern Australia until the mid $1800 \mathrm{~s} .{ }^{15}$ As a penal colony, the British Colonial Office (BCO) in London determined economic and political policy, including land policies. ${ }^{16}$ The representative of this office in NSW, the colonial governor, a military administrator, oversaw the implementation of directives received by the BCO. During the late $1820 \mathrm{~s}$, the BCO attempted to concentrate settlement within an area known as the Nineteen Counties - the legal limits of settlement. ${ }^{17}$ However, several factors caused the spread of population beyond these boundaries to the frontier: 1) population increases resulted in land scarcity within the settlement limits (Roberts, 1935); ${ }^{18}$ 2) land prices within the Nineteen Counties were high, set at a minimum price of $£ 1$ per acre; ${ }^{19} 3$ ) growing demand and rising prices for Australian wool in Britain increased the net present value accruing from land settlement outside the boundaries (Imlah, 1950; Butlin in Vamplew (ed.) 1987); ${ }^{20}$ and 4) inadequate police numbers made the boundaries unenforceable.

Land occupation outside the Nineteen Counties was illegal and these settlers became known as squatters. ${ }^{21}$ Squatters $(K)$ preceded labor $(k)$ to the frontier because capital reaped its opportunity cost

\footnotetext{
${ }^{15}$ Tasmania, Victoria, and Queensland became separate colonial jurisdictions during the $1850 \mathrm{~s}$.

${ }^{16}$ Captain James Cook declared the Australian east coast British territory in 1770 . On settlement in 1788, the British Crown declared the continent 'terra nullius' specifically, the land belonged to no one. This pronouncement implicitly denied the existence of ownership rights by first inhabitants thereby dispossessing Australian Aboriginals under the British territorial claim. It followed that all land in Australia, unless expressly granted to individuals as free hold, was owned by the Crown.

${ }^{17}$ Settlement concentration was in part a result of the need to restrain the convict element, but it was also attributable to the influential writing of colonial theorist, Edward Wakefield an exponent of systematic colonization. Roberts, 1924; Crowley (1980); and Kociumbas (1988) provide lengthy discussions of Wakefieldian theories.

${ }^{18}$ Of significance is the increase in 'free' population (excluding military and convicts) that is, migrants entering NSW. During this period, free population increased from 12, 846 in 1820 to approximately 50,000 by 1836 (Vamplew, 1987; Roberts, 1935).

${ }^{19}$ Burroughs (1967) argues that 11 per acre was in excess of the productive value of colonial land due to enormous quality variation impacting it's suitability for agriculture.

${ }^{20}$ Imlah's (1950) wool price index for the United Kingdom uses Spanish, Leonesa, Saxon, and Australian price series to construct estimates from 1822 to 1880. Butlin's series (Table PC 106-107) in Vamplew (1987) is for Australian greasy wool 1850-1969.

${ }^{21}$ Initially, the term 'squatter' was used to identify individuals who illegally occupied Crown land within the settlement boundaries. Evidence suggests these individuals were made up of a mix of those given land grants who occupied adjacent land to which their grant did not extend; as well as convicts with tickets-of-leave or conditional pardons. Ticket-of-leave convicts were given the right to work or live within a given district before their sentence expired or they were granted a conditional pardon; convicts who obtained conditional pardon were released on the condition that they did not return to England or Ireland. However, after 1825 exploration across the Blue Mountains accelerated the movement of squatters outside the Nineteen Counties (this area was defined in 1827).
} 
before labor, corresponding to the region between $G C J$ and $H D K$ in Figure 2. Beyond the legal boundaries of the Nineteen Counties, land was not scarce and squatters occupied where they pleased corresponding to the distances between points $J$ and $K$ in Figure 2. Australia's arid climate and economies of scale in wool production resulted in large land claims on the frontier, on average between 24,000 and 34,000 acres (Roberts, 1935). ${ }^{22}$ The size of claims meant individuals were unable to effectively enforce their claims against entrants so squatters employed at least one hut keeper on each parcel to enforce ownership against later arrivals. In our taxonomy in Table 1, this was first party specification with third party enforcement. Property boundaries were vague, typically defined by natural features including rivers and marked trees. It would be expected that the combination of the lack of de jure rights and imprecise boundaries would increase the potential for conflict among squatters as scarcity increased. However, there is little evidence of actual conflict. In part, this may have been the result of third party enforcement that included strategically placed huts across a claim and a physical presence of employees on runs; but, there is also evidence that informal norms played a role. At this point there was first party specification with a combination of both second (district squatters) and third party (employees) enforcement. Two main factors encouraged the creation of informal rights that lead to second party enforcement by squatters to protect land claims: 1) the illegality of their occupation and 2) the violence potential of Aboriginal tribes. As noted, squatters outside the Nineteen Counties occupied land illegally. Any conflict between them violent or otherwise brought the possibility of all claimants being dispossessed by colonial administrators. Correspondence between early settlers in the Port Phillip district (Victoria) of NSW explicitly acknowledges this incentive in dealing with encroachments stating:

it would afford the Government pretext for interfering...there is plenty of room for all who may come, and it would be good policy for us as the leading party to set examples of good fellowship, and establish the principle of non-interference as is done in the back settlements at Sydney (Port Phillip Association, Wedge to Batman 3 September, 1835).

This suggests the potential rents from occupation were high enough to encourage cooperation to enforce claims against newcomers and prevent government dispossessing all claimants. Further, squatters settled on land occupied by Aboriginal tribes. Initially, these tribes had a distinct violence advantage compared with squatters. ${ }^{23}$ Any violence between squatters had the potential to incite local

\footnotetext{
${ }^{22}$ Eighty percent of Australia receives less than $600 \mathrm{~mm}$ of rain per annum. On average, one sheep requires 3 acres of grazing land.

${ }^{23}$ There is little evidence that Aboriginals were hostile to white settlers during the early period of occupation. Later, when squatter numbers increased, the violence advantage went against the Aboriginals and there is
} 
tribes. In turn, de facto property rights with first party specification and second party enforcement acted to limit dissipation of rents by reducing conflict between squatters as well as preventing Aboriginal violence against settlers (Port Phillip Association, Ball to Mercer 25 February 1836). Homogeneity and the small numbers of early squatters underpinned these more explicit incentives to encourage cooperation.

Roberts $(1924,1935)$ and Weaver (1996) suggest that, at least during the early 1830 s, prior to choosing a run; newcomers to an area would negotiate with any neighbors as to property boundaries. One of the earliest squatter's in NSW noted:

It is of great importance not to embroil the Establishment by disputes with neighbours, and (without, however, weakly giving away to unreasonable objections, and though distance is no doubt an objective), I think an extensive good Run, not subject to be encroached upon, may sometimes more than compensate for remoteness (Hogan Papers, 1830-4 quoted in Roberts, 1935, p. 278).

Where conflict over boundaries did occur, arbitration by other district squatters could be used to determine the rights of claimants. Each claimant would nominate one arbitrator and those two would then select a third representative. Once the arbitrators were chosen, the process was relatively formal with written decisions binding administrators and executors of the disputants; majority rule decision making; and the allocation of costs to each party. For example, in a boundary dispute between William Adeney and his neighbor, John Manifold, arbitration documents provide a description of the dispute, names and residences of disputants, and a sketch map of the final boundaries (Adeney, 1845-47). Moreover, the documents note the decision had the same effect of creating a rule for the district as did those of the NSW Supreme Court (Adeney, 1845-47).

Evidence suggests that while land claims were subject to first party specification with a combination of second and third party enforcement, second party specification and enforcement was used to delineate other key aspects of a squatter's rights. Specifically, second party specification and enforcement defined rules of abandonment for each district (Weaver, 1996) and maximum number of sheep per flock (Curr, 2001). The absence of sheep on a run constituted abandonment however, district rules permitted periods of non-use that did not amount to abandonment. For example, in the New England district of NSW, a run could be left unstocked for a period of six months before it was declared abandoned (ANSW 4/3660, Macdonald to Colonial Secretary Thomson, 24 August 1844). Implicitly, nonuse periods recognized the seasonal nature of grazing with respect to water availability and grass supplies as well as distance from market. All district squatters had an incentive to enforce these rules 
because they all faced the same seasonal and distance constraints. Maximum flock size was considered approximately 520 sheep. There were two reasons for limitation: one internal to the user and the other external to other users: 1) localities in which sheep first grazed in NSW were scrubby, creating the potential for large losses due to the inability for one shepherd to manage a flock larger than 520 (Curr, 2001); ${ }^{24}$ and 2) if flocks numbered over 520, it was believed that pastures over which the flock travelled would be wasted and stronger sheep would consume the bulk of the grass. Given flock relocation often took place via the use of common stock routes, on which sheep still need to graze, norms dictating flock size reduced the likelihood of overusing common pastures for relocation. Limiting flock size also reduced the trampling of grass on private land, decreasing the costs associated with sheep having to travel for food (Roberts, 1935). These norms were collective goods that had private benefits, corresponding to differences between areas $O F B I$ and $O G C J$ in Figure 2.

By the late 1830s, increasing scarcity values led squatters to appeal to colonial administrators and the British government for recognition of their land rights and more secure de jure property rights. ${ }^{25}$ In other words, squatters were moving toward $\mathrm{O}$ in Figure 2, requiring them to spend greater time and effort to enforce their land claims and the incomes derived from the resource. The demand for greater security was not driven by a need to access formal capital markets because mortgages and credit were acquired relatively easily from British banks in the colony and from private investors. Creditors were willing to accept sheep as collateral. Instead, it was to ensure that the rights of squatters were enforced against an increasing number of newcomers to the frontier brought about by the continuing pastoral boom. In other words, de facto rights, where first party specification was combined with second and third party enforcement, was no longer sufficient to defend claims against encroachment.

As noted, the BCO determined colonial land policy which attempted to restrict population to the area within the Nineteen Counties. Nevertheless, in addition to squatters' demand for de jure rights, expansion of settlement beyond the boundaries had led to the creation of two explicit incentives for the BCO to supply more formal rights: 1) NSW had become a critical supplier of wool to British manufacturers increasing the political and economic importance of Australian land policy for the British parliament (Burroughs, 1967; Dingle, 1984); and 2) any failure to regulate occupation led to possible claims of adverse possession via the courts. Continuing the large quantity and high quality of wool imports from NSW required unconstrained settlement, as the colonial Governor, Richard Bourke advised the secretary of the BCO:

\footnotetext{
${ }^{24}$ Convicts were early shepherds and they had little incentive to prevent sheep losses.

${ }^{25}$ Burroughs (1967) discusses in some detail the nature of squatters' lobbying activities in Britain during this period, pages 315-319.
} 
I cannot avoid perceiving the peculiarities which, in this colony, render it impolitic and even impossible to restrain dispersion within limits that would be expedient elsewhere. The wool of NSW forms at present, and it likely long to continue, its chief wealth. It is only by free range over the wider expanse of native herbage which the colony affords that the production of this staple article can be upheld, at its present rate of increase in quantity, a standard of value in quality. The proprietors of thousands of acres already find it necessary, equally with the poorer settlers, to send large flocks beyond the boundary of location to preserve them in health throughout the year (Braim, 1846).

Further, the common law rule of adverse possession gave squatters' (trespassers) an avenue by which they could transfer their occupation into freehold title if the owner of the land (the Crown) failed to act to prevent the trespass within a certain timeframe, usually 20 years. ${ }^{26}$ However, the BCO was reluctant to recognize formal titles for squatters' land claims because this would require ceding potential revenue from later sale. ${ }^{27}$ Instead, the BCO introduced annual squatting licenses (Act $7 \mathrm{Wm}$. IV., No. 4) that acquiesced squatters' demands for de jure rights while retaining Crown ownership. Under the license system, squatters paid $f 10$ annually to occupy as much land as they pleased. In our taxonomy of specification and enforcement, licenses supported existing first party specification but transferred enforcement to government. Licenses gave squatters occupancy rights and were enforceable against all parties except the Crown. Therefore, the Crown could evict squatters at any time without compensation. Despite this, there continued to be an active market for squatters' runs. $^{28}$ Licenses expressly forbade squatters from using land for agricultural purposes. The extent of crop production that could take place was restricted to a size and quantity sufficient to supply individuals living or working on the 'run'. The license system was enforced by Crown Lands Commissioners appointed in each of the seven districts outside the Nineteen Counties. Commissioners had authority to refuse license renewal, determine boundary disputes and claims of trespass. The BCO appointed border police to enforce the decisions of Commissioners should squatters fail to comply. Clause 10 of the legislation appointing Commissioners to each district, instructed them to act "according to the established usages and customs of the Colony" (emphasis ours). ${ }^{29}$ Any departure from custom established by usage required government sanction (ANSW 4/3660, Colonial Secretary Thomson to

\footnotetext{
${ }^{26}$ Adverse possession had foundation in the English common law rule of disseisin that allowed a trespasser to acquire imperfect possessory rights that could evolve into perfect legal title if the legal owner did not act to prevent a trespasser. In Australia, the legal owner was the Crown and unlike in some jurisdictions, historically individuals could take action for adverse possession against the Crown (a rule that today is codified in statute law of Australian states).

${ }^{27}$ Revenue from sale was to fund migration.

${ }^{28}$ As we discuss in the next section, early claimants in the U.S. sold their informal claims indicating that the commons arrangements prevented dissipation.

${ }^{29}$ An Act to continue and amend an Act intituled [sic] "An Act to restrain the unauthorized occupation of Crown Lands" (2 Vic., No. 19, 1838).
} 
Lambie, 29 November, 1843). Therefore, licenses created a mix of both de facto and de jure property rights on the frontier. For much of the next decade, squatters continued to petition the colonial governor for greater ownership security because licenses did not alleviate problems of vague boundaries. Moreover, Crown Land Commissioners faced information constraints so that third party government enforcement was subject to some contention leading to appeals to the Colonial Secretary and the governor (ANSW 4/3660, Colonial Secretary Thomson to Lambie, 18 April 1842; ANSW 4/2680 Aitken to Governor George Gipps, 25 March, 1845). A continuation of lobbying efforts indicates growing competition for land so that informal rights were no longer sufficient to protect the claims of squatters. It was at this point that increased potential value, the area measured by $A B F$ in Figure 2, would accrue in a move to third party government specification and enforcement.

Squatters secured greater de jure rights by the middle of the 1840 s with the introduction of longer leases accompanied by pre-emptive rights to a proportion of the land occupied. ${ }^{30}$ Leases (third party government specification) retained a measure of first party specification and third party enforcement but provided surety of tenure that was absent with annual licenses. Leases could be granted for one, eight or 14 years depending on a run's location in the colony. Specifically, a run in 'settled' districts (within the Nineteen Counties) could only acquire a one year lease; a run in 'intermediate' districts (areas immediately surrounding the Nineteen Counties) acquired an eight year lease; and in 'unsettled' districts on the frontier, a run could acquire a 14 year lease. Further, the government set rentals at a minimum of $£ 10$ for 4,000 sheep with an increment of $£ 210$ shillings for every 1,000 sheep thereafter. Under these regulations, during the duration of the lease, land could only be sold to the occupier. On a lease's expiration squatters could claim pre-emptive rights to one block of 640 acres (one square mile) for every 16,000 acres ( 25 square miles) of leased land at $£ 1$ per acre.

Squatters mix of de facto and de jure rights remained relatively unchanged until the mid-1850s. By this time, the limited availability of gold caused a now expanded population to pressure government for land reform. Once gold was nearly exhausted, former miners' opportunity costs of moving to the frontier fell so labor was now in the region ohdk in figure 2, and many ex-miners wanted to turn to agriculture for a living. Paralleling this, NSW had been divided into four separate colonies, NSW, Port Phillip (Victoria), Moreton Bay (Queensland), and Van Diemen's Land (Tasmania). ${ }^{31}$ On separation from

\footnotetext{
${ }^{30}$ Leases were granted under "An Act to amend an Act for regulating the Sale of Waste Land belonging to the Crown in the Australian colonies, and to make further Provision for the management thereof" (9 \& 10 Vict. cap. 104, 1846).

${ }^{31}$ Victoria was granted separated in 1850; Tasmania in 1856; and Queensland in 1859. Western Australia (WA) and South Australia (SA) were settled in 1827 and 1834 respectively, independently of NSW. WA, initially a free
} 
NSW each colony was granted responsible government that is, the right to legislate over its own affairs, including land policy. Moreover, each of the four colonies now had parliaments elected by the population. These political changes were critical in terms of determining the supply of de jure property rights to land.

Prior to separation each colony had representatives on the NSW Legislative Council. The Council was made up of a number of elected individuals as well as a number appointed by the governor. However, the Council remained an advisory body with the governor retaining executive power. Responsible government reduced the power of the governor to the sovereign's representative in a colony. Executive power was concentrated on the various ministers appointed from parliamentary representatives by the nominated parliamentary leader, referred to as the Premier. Premiers were leaders of factions that formed a majority in the parliament. The organization of parliaments followed the Westminster system that is, a two house legislature made up of the Legislative Assembly (lower house) and the Legislative Council (upper house). Election to the upper house remained subject to property qualifications that resulted in a disproportionate representation of squatting interests for much of the nineteenth century. ${ }^{32}$ However, the introduction of universal male suffrage in the late 1850s diluted squatters' political power. Moreover, fear of social unrest and the potential for violent uprising similar to the riot which occurred at the Ballarat gold field in 1854, referred to as Eureka Stockade exerted an important influence on squatters' support for land reform legislation. ${ }^{33}$

The Eureka Stockade was a critical turning point in colonial politics. Bate (1988: 46) argues this uprising generated a shock-wave that helped carry constitutional reforms that may otherwise have "founded on the rocks of upper house opposition." In 1856 Victorian ex-miners formed the Victorian Land League calling for the introduction of legislation to allow them to select 650 acres of agricultural land in the colony. ${ }^{34}$ By 1860 , parliament's failure to pass several reform measures led to a riot of

settlement, was founded by Captain James Stirling. However, in order to increase labor supply, in the 1830s it became a penal colony administered by the British Colonial Office. SA was established via Imperial legislation (South Australia Colonisation Act 4\&5 William IV).

${ }^{32}$ For example, in $186529 \%$ of the members of the NSW Legislative Council came from pastoral occupations, compared with $16 \%$ for the next largest occupational group, lawyers. By 1890, 33\% of members came from pastoral occupations, compared with $20 \%$ lawyers (Hawker, 1971, Table 24, p. 147).

${ }_{33}$ Ballarat was Victoria's largest gold field and the Eureka Stockade was the pinnacle of tensions between miners and local officials that had been building from 1852. These tensions primarily resulted from the high costs of the miner's license fee and miners' desires for parliamentary representation. Additional factors continued to exert pressure on this already tense situation which Bate (1988: 45) argues pushed "the protest movement...into a rebellion." The clash between miners and police lasted approximately 15 minutes with about 30 deaths.

${ }^{34}$ Evidence suggests the Victorian Land League was formed by Chartists, who were agitating for land reform in Britain. Chartists migrated to Australia in two waves: as convicts, sentenced for transportation as punishment for political uprisings in Britain; and as migrants during the gold rushes. Chartists had their origins in the formation of 
20,000 outside the chambers. Similar political movements were formed in NSW, specifically, the NSW Land League in 1857 however, while political uprising did not occur there, the possibility was not far from legislators minds. As a result, the potential or actual social unrest caused by agitation for land reform caused squatter dominated upper houses to pass reform legislation and rely on their significant home court advantage to defend their claims. ${ }^{35}$ These factors resulted in a divergence between de facto and de jure rights with first party specification combined with third party enforcement being replaced with third party government specification and limited government enforcement.

Squatters' (incumbents) home court advantage was relatively large even though reform legislation favored a redistribution of de jure rights to ex-miners (entrants). The relative strength of this home court advantage was a function of the economic clout of squatters' which had been increased by three factors discussed in section two: 1 ) squatters' settlement at the frontier was brought about by high benefits of sheep grazing not their low opportunity costs of relocating to this region. As a result, larger rents accrued to these settlers during their uncontested occupation, increasing their economic clout; 2) squatters' had a greater head start than ex-miners in exploiting the returns from land occupation. In other words, the distance between $K$ and $k$ in Figure 2, was large, increasing squatters' wealth over time; and 3) rents accruing to squatters' from formal land rights were higher than for exminers as a group that is, $A B F>a b f$ in Figure 2. Further enhancing the economic dimensions of their home court advantage, squatters' had better information about the quality of land at the frontier and it's suitability for sheep grazing compared to agriculture. Evidence suggests that in the short run, squatters succeeded for the most part in protecting their land claims even though reform acted to curtail the extent of their de jure rights.

To better understand this success we need to analyze the legislation facilitating reform and the various roles played by special interests that oversaw reform - the colonial Lands Departments and parliament. Land legislation in the 1860s embodied two guiding principles: land selection before survey and phasing out squatters' leases. ${ }^{36}$ Each colony introduced similar requirements for individuals to purchase land under selection in terms of land prices, residence expectations, and investment conditions. Selection permitted anyone to purchase no more than 320 acres at $f 1$ per acre, payable

London's Working Men's Association (1836) that campaigned for social and political equality of working classes. Simms (2006), McIntyre (2004) and Toscano (2007) all discuss the impact of the Chartist movement on Australian politics during the nineteenth century.

${ }^{35}$ Squatters' British political influence had been reduced by constitutional reform and therefore, they could not lobby the British parliament to support the continuation of their de facto and de jure rights.

${ }^{36}$ WA and SA were the exceptions; WA remained a British colony until 1890, all land policy was determined by the British Colonial Office; and SA never introduced selection before survey. 
over a period of three years. A deposit per acre was required at the time of registration, the balance of which became payable at the end of the three year period. Regulations required 'selectors' to reside on the land for the entire three years and to invest in 'improvements' for instance, fences and buildings, to the value of $f 1$ per acre, per annum. Later requirements also included expectations that selectors would cultivate a proportion of the land. Selections could be transferred to another party after one year's residency. On expiration of the three year conditional purchase, selectors could buy the land or transfer the claim to a seven year lease. If claims were transferred to a lease, rental payments required would contribute towards purchase when the lease expired. Regardless of whether the land was purchased or leased at the end of the three year term, the selector must have fulfilled the conditions. To do this, they simply had to sign a statutory declaration that they had had fulfilled the residence, investment, and cultivation requirements. Agents of the Department of Lands were expected to inspect properties to ensure the declarations were correct, but more often than not they simply took for granted that selectors were bona fide.

Squatters' retained pre-emptive rights to purchase 640 acres from each 16,000 acres at a price of $£ 2$ for each section and they could also select 320 acres of their runs in line with selection clauses. If they exercised pre-emptive rights, they were also entitled to lease three times this area for a maximum of 14 years with rentals determined by stock carrying capacity. In other words, the maximum area of a squatter's de jure rights was approximately 2,560 acres, plus 320 acres if they filed for selection. Recall, on average, squatters de facto claims of the 1830 s and 1840 s were between 24,000 and 34,000 acres. As a result, selection legislation substantially curbed the extent of squatters land subject to de jure rights.

Land reform increased the potential for conflict because the holdings of squatters not claimed under pre-emption lease were now subject to government sanctioned competition by selectors. The increase in conflict potential was a result of the substantial divergence between de facto and de jure rights brought about by a move to third party government specification that undermined incumbents prior de facto and de jure specified rights. Land Departments administered the application of the legislation, appointing Land Agents in each district to file selection claims. Agents sent the applications to Departments for registration on a weekly basis. Once registered, a survey would be requested. However, prior to the survey taking place, the Lands Departments would update district maps as to the location and boundaries of the claim based on descriptions provided by applicants to Land Agents. District agents used the revised maps to record subsequent claims. The principle of selection before 
survey imposed an ex-post problem for administrators brought about by information asymmetries constraining the effectiveness of third party government enforcement.

Information asymmetries arose because neither Land Agents nor claimants were in a position to accurately define boundaries of selected land thereby reducing the effectiveness of third party government enforcement. These problems were only alleviated after a survey had taken place. Therefore, any delay between a land claim and survey increased the potential for conflict. For this reason, survey activity had a lagged effect on the potential for conflict. Consequently, a low number of surveys in any one year would increase the probability that some selections were invalidated in future years. Evidence from NSW suggests that due to the undersupply of qualified surveyors, the lag between selection and survey was approximately nine to 12 months (Morris and Ranken, 1883).

Claims could be invalid for several reasons : 1) the parcel selected infringed on government reserves that is, land set aside for public purposes such as access to water sources; 2 ) land selected was owned by squatters under pre-emptive or claimed under lease rights. In part, the inability to accurately identify areas to which pre-emption applied was a result of imperfectly defined boundaries of squatters' properties that persisted over time. A typical description of squatters' boundaries:

It followed Mr. Whyte's ploughed line as far as a rock described by Mr. Grant as situated about 350 yards from a tea-tree sapling (should it not touch the rock to be drawn from the nearest point), then a straight plough-furrow to be drawn to the intersection of Mr. Henty's plough-furrow with a creek or marsh (Henty to Geelong Crown Lands Commissioner, quoted in Roberts, 1924: 179).

In turn, Crown Land Commissioners, responsible for recording the property boundaries of squatters within their district, were often unable to exactly identify these areas. As a result, some areas opened for selection were legally retained by squatters under pre-emption and associated leases. However, selectors and Land Agents had no way of knowing this until surveys had been completed and boundaries defined. As a result, the potential for conflict between squatters and selectors was positively related to the extent of pastoral occupation in a colony; and 3) claims could be invalid because land had been applied for earlier by another selector. As the number of surveys increased, a higher number of invalid claims would be identified and subsequently voided. However, in the years preceding survey, invalid claims were the source of potential conflict between squatters and selectors, as well as between selectors. Potential for conflict would also increase with the number of selections per annum. ${ }^{37}$ As the number of selections increased so too would information asymmetries caused by inaccurate district maps resulting from survey delays. The greater the number of selections, the higher the probability that

\footnotetext{
${ }^{37}$ As you can see in Appendix 2 the number of selectors increased significantly over time, peaking in 1874.
} 
areas claimed formed part of squatting properties with unclear boundaries or incorporated land already claimed by another selector.

Compounding the problems accompanying the very principle of selection before survey was the inefficiencies and understaffing of the surveying branches of the Land Departments. In part, selection before survey was intended to overcome this constraint to the extension of settlement. However, the lack of qualified surveyors in Australia delayed surveys, leading to a large number of claims being revoked over time (refer to Appendix 3 for extent of revocation per annum in NSW and Victoria). The result was that while land reform created competition between squatters' (incumbents) and selectors (entrants), there was a lack of enforcement of selectors' rights. Entrants' rights could only be enforced if the extent of those rights relative to incumbents were clearly defined. Evidence suggests that the undersupply of surveyors resulted in a lack of definition that consequently reduced the Lands Departments and parliaments' ability to enforce the new entrants de jure rights simply because they could not accurately identify their location. In turn, this increased squatters' home court advantage. The undersupply of surveyors remained a significant problem well into the 1870s. As a result, selection was accompanied by third party government specification but took place in the absence of effective third party government enforcement because of information asymmetries and the undersupply of surveyors in Australia. Perhaps surprisingly, while the potential for conflict remained large, there is little evidence of actual violence occurring during the selection period (1860 to 1884). Rather than a comparative violence potential mitigating violence, as we will see was the case in the U.S. West, our explanation for the lack of conflict on the Australian frontier arises from the economic and political clout of squatters. This acted to strengthen squatters' home court advantage allowing them to take advantage of legislative loopholes to defend their land claims. In other words, squatters' economic and political power allowed them to ensure a lack of third party government enforcement and use first party enforcement to defend their claims.

Squatters' used their wealth and influence to evade reallocation attempts effectively insulating them against redistribution. There were several methods by which evasion would take place: 1) "dummying"; 2) "peacocking"; and 3) forcing an auction. Dummying involved squatters' contracting with agents, often employees, to select part of their run, register the claim with the Department of Lands (often under false names), and then sell it back to the squatter for a small fee. ${ }^{38}$ By employing dummies to protect claims, squatters were utilizing third party enforcement. Legislation made this

\footnotetext{
${ }^{38}$ In the U.S., ranchers also had hired men file for homestead claims for which the ranchers subsequently reimbursed their employees.
} 
possible because, up until 1880, a selector could transfer their claim after only one year of residence. Numerous parliamentary inquiries suggest the extent of dummying was widespread employed by both squatters and selectors. ${ }^{39}$ Squatters' wealth advantage permitted them to undertake this practice on a much larger scale increasing the likelihood they retained large portions of their original holdings.

Data pertaining to the number of selections transferred in NSW from 1862 to 1882, suggest over $50 \%$ of original claimants sold their land (Morris and Ranken, 1883 (refer to Appendix 4 for transfers per annum in NSW)). In itself, this does not suggest that all these transfers were from dummies to squatters, some transfers may have been the result of climatic factors that caused agriculture to fail. Specifically, beyond the boundaries of the original Nineteen Counties (from the coast, approximately 200 miles inland), rainfall was less than 20 inches per year making permanent crop production almost impossible. Selectors, who were already capital constrained, could not raise the funds required for investment to supplement surface water supplies. Moreover, the blocks of land allocated under selection were far too small for these settlers to graze sheep, a naturally drought tolerant animal, suggesting the arid climate may have led to a number of selections being transferred. These transfers may well have been to district squatters, but it was the premature actions on the part of politicians that introduced selection that predicated this outcome rather than evasion by squatters. Nevertheless, evidence suggests that dummying may have been responsible for a large proportion of these transfers because once legislative amendment prevented transfer before the expiration of three years residency, the number of transfers drop dramatically from an average of $59 \%$ to less that $1 \%$ (Morris and Ranken, 1883).

'Peacocking' was another method by which squatters used their wealth to avoid redistribution of their estates. Peacocking was a practice used primarily by dummy selectors who would pick the vantage points out of a squatting property so as to render the intervening land useless (Roberts, 1924). For example, a squatter would have his agents strategically select parcels of his original holdings to create contiguous water frontage access. This would render the intervening land useless for any other selector, thereby allowing the squatter to retain the bulk of his run. The information advantage held by squatters' and their employees as to land quality assisted them in this practice.

\footnotetext{
${ }^{39}$ For anecdotal evidence on the extent of dummying refer to NSW, Select Committee on the Administration of Land Laws, Minutes of Evidence, $2^{\text {nd }}$ Progress Report, Legislative Assembly, Votes and Proceedings, 1872/3; NSW, Select Committee on the Administration of Land Laws, Minutes of Evidence, 3rd Progress Report, Legislative Assembly, Votes and Proceedings, 1873/4; Victoria, Board of Inquiry into proceedings in relation to certain land selection in the Wimmera District, Legislative Assembly, Votes and Proceedings, 1873; Victoria, Crown Land Department Board of Inquiry, Legislative Assembly, Votes and Proceedings, 1874.
} 
The final tactic squatters used to evade redistribution was to force land to auction. There were two options available for squatters to do this; 1 ) by selecting the same area as a bona fide selector. If the same parcel of land was chosen by more than one selector, legislation required it was to be put up for public auction; and 2) squatters could employ agents to select multiple parcels and then forfeit these claims. As in the case of multiple selectors, once forfeited, land had to be auctioned. Evidence suggests that between 1862 and 1882 in NSW, on average, 12\% of selections were forfeited (Morris and Ranken, 1883 (refer to Appendix 4 for forfeitures per annum in NSW)). However, this may have included selectors who forfeited their holdings because climatic and economic conditions were not suited to permanent agriculture. Moreover, these statistics suggest that compared with dummying, forfeiture may have been less prominent. Nevertheless, forfeiture allowed squatters' to evade redistribution to some extent because at auction capital constrained selectors were unable to outbid squatters. ${ }^{40}$

Three additional factors complemented the wealth advantage of squatters' increasing their home court advantage and thus, their ability to secure de jure rights: 1 ) declaring a public reserve. The ability for squatters to declare public reserves was a direct result of a lack of qualified surveyors in Australia. In formulating land reform, parliaments realized that some land should not be subject to selection as it would, at some future point, be required for public uses - this was particularly true in terms of water supply. However, during the initial period of selection, a limited supply of surveyors led parliaments to have squatters identify and nominate suitable areas of reserves. In doing so, parliaments gave squatters' an incentive to overestimate the area required for public purposes thereby insulating part of their runs from selection until after surveys could be carried out. Moreover, because surveyors' priority was to survey land claimed under selection, there was a considerable lag time between when a reserve was declared and when it was surveyed. During the intervening period, squatters' exploited these areas to water stock and wash wool. ${ }^{41}$ A NSW parliamentary inquiry estimated over five million acres of reserves were drawn up by squatters themselves (NSW, VP, 1872); 2) information asymmetries on land quality concerning its suitability for agriculture; and 3) much of the area open to selection was arid, and unable to support small scale permanent agricultural production. ${ }^{42}$ The inherent mobility advantages of sheep grazing made the activity drought tolerant with sheep able to be moved long distances at low

\footnotetext{
${ }^{40}$ Squatters were wealthy compared with selectors at the time land reform was introduced however, they also had a wealth advantage in that they could access relatively cheap capital because legislation permitted them to use their stock as security for mortgages. Further, they could put liens on their wool to access credit in periods where they may face capital constraints.

${ }^{41}$ Prior to shearing, wool washing reduced the weight of wool and thereby, its transport costs (Butlin, 1964).

${ }^{42}$ The same situation arose in the U.S. west where many homestead claims subsequently were abandoned because the land could not support agriculture (Libecap and Hansen, 2004).
} 
costs and therefore, more suited to the more arid parts of the frontier. As a result, agriculture on the frontier produced a lower rental stream from land than did sheep grazing. This was compounded by the lack of transport infrastructure to urban markets and high costs of cyclical drought.

These multifaceted approaches to evasion and low returns to agriculture allowed squatters to prevent the reallocation of their land for much of the selection period. In our specification and enforcement taxonomy selection took place with third party government specification and enforcement but enforcement was constrained, and in some cases, entirely absent. The lack of third party government enforcement was a critical factor that limited the transfer of de jure rights to new entrants. Counterfactually, the absence of effective government enforcement may have acted to reduce the number of settlers filing for selection. Moreover, squatters' evasion efforts, employing both first and third party (agents) enforcement, were instrumental in the failure of selection to effectively redistribute colonial lands to small holders. Roberts (1924) states that in NSW over the period of selection eight sections out of every nine passed to original occupants and, by 1883, over eight million acres of colonial land was owned by 96 individuals. Further, Morris and Ranken (1883) note that by the middle of the 1880 s on average, only $27 \%$ of selectors remained on the land arguing that selection had resulted in: "Unintelligible chaos, in which the rights and interest of all mainly concerned have been the sport of accident, political interest, and departmental disorder."

Squatters extensive evasion efforts suggests two things: 1) for much of the 20 years of land reform, squatters placed a higher value on the land than selectors that is, the size of the wedge $O A C J$ was greater than oacj in Figure 2 and; 2 ) the size of squatters pre-emption claims were too small (Harris, 2008). ${ }^{43}$ Squatters used their wealth to (illegally) obtain de jure rights in the form of longer term security of tenure denied to them by colonial governments. ${ }^{44}$ In part, this was a function of the continuing pastoral industry boom which ended in the mid-1880s. ${ }^{45}$ In short, Australian land reform efforts suffered from the premature promotion of settled agriculture at the frontier, prior to it being profitable. Further, third party government specification was not accompanied by effective third party government enforcement. Both of these factors had the benefit of producing little actual conflict between squatters and selectors, a situation that also transpired in the high plains of the U.S. West.

\footnotetext{
${ }^{43}$ The restriction on size in arid areas parallels the U.S. case.

${ }^{44}$ In the 1840s, squatters had lobbied for leases up to 26 years in duration. The colonial governor and the BCO did not approve of this as it would have acted to constrain revenue from later sale. The revenue later played ay a critical role in assisting migration to the labor scarce Australian colonies.

${ }^{45}$ By that time, the introduction of further land reform to induce cooperative settlement underpinned by irrigation and accompanied by government funding to voluntarily acquire squatting runs, led to a migration of the many early frontier settlers to urban areas.
} 


\section{Settlement of the U.S. Frontier}

There have been numerous studies on the overall pattern of settlement of land in the U.S. Here we want to focus on the settlement of the frontier in the Great Plains, which was occupied by cattlemen, after the expulsion of Native Americans. ${ }^{46}$ We focus on the Great Plains because the land was relatively arid and as such its economic value at the time of settlement did not warrant paying the governmentally fixed price of $\$ 1.25 /$ acre. Nevertheless, the region had economic value for ranching, which is a relatively capital intensive activity. ${ }^{47}$ For the first arrivals the land was not scarce and ranchers were free to occupy where they pleased - this was first person specification and self-enforcement. In terms of Figure 2 in Section II, the reason that cattlemen preceded labor to the frontier of the Great Plains was that capital reaped its opportunity cost prior to labor. In Figure 2 this corresponds to the economic frontier occurring for cattlemen at distance $K$ from the market center - a connection to the railroad for cattlemen. This was the situation shortly after the Civil War.

The Great Plains naturally consisted of a set of ranges. Dennen (1976: 424) defined a range "as the watershed of a stream, with the provisions that cattle must drink water at least once a day, and the extent of a particular range is limited by the distance cattle can wander in 1 day. This is in the neighborhood of 5 to 10 miles." The watershed was the basin between two valleys and cattle typically did not cross valleys but tended to meander within a valley. Over time it was difficult to establish exclusivity to an entire range because entrants would have an incentive to come to the range as long as cattle prices increased and/or the railroad network expanded. In the early years of the post civil war period, the costs were small. But, besides the externalities associated with grazing, once cattle with different owners occupied the same range the issue of ownership arose.

To establish ownership over their cattle, ranchers branded their cattle and ranchers needed to have exclusivity to a single brand. On local ranges, it was simple enough for ranchers to recognize brands, but some cattle would stray across ranges and over time ranchers acted collectively first through local associations, later state-wide associations and subsequently with legislative approval. This entailed a mixture of first and second person specification with second and third party enforcement. The first territorial legislative assemblies in Montana (1865) and Wyoming (1869) established registration

\footnotetext{
${ }^{46}$ There are many general accounts of the open range period, including Briggs (1940); Dale (1960); Nimmo (18841885); Osgood (1929); Pelzer (1936); Robbins (1942); and Sandoz (1958). We relied on these accounts for general overviews. On the specifics of cattlemen's arrangements and their economic rationale we relied heavily on Anderson and Hill (2004) and Dennen (1976).

${ }^{47}$ Dennen (1976: 423) estimated the land was worth \$1.00/acre for ranching.
} 
systems (Anderson and Hill, 2004: 149). The registration system of brands established clear ownership over cattle and thereby facilitated sales of cattle and limited cattle rustling.

If branding was the only problem in establishing exclusivity then there would not have been any further need for collective action once a registration system was overseen by an organization, e.g. the Wyoming Stockgrowers' Association, or the government. But, ranchers faced two threats to the productivity of their ranges - this means that ranchers were now in the region to the left of $J$ Figure 2. Current occupants of the range would have an incentive to overstock the range as long as the private benefit was positive. In addition outsiders would have the same incentive to enter a range as long as the private benefit was positive. Despite these gains, it is not obvious that cattlemen's associations would emerge to solve these problems because of the familiar free rider problem. ${ }^{48}$ Three factors increased the likelihood that commons arrangements would emerge: 1) the number of ranchers on a single range was not large; 2) initially, ranchers were quite homogeneous facilitating cooperation; and 3) ranchers had to perform a roundup which not only had economies of scale but, if performed multiple times, inflicted costs on the cattle.

A "roundup" was a bi-annual activity of collecting the cattle that roamed over the range. Given the aridity of the region, cattle needed to roam relatively great distances in order to find adequate forage. In the spring, the round-up allowed ranchers to assess damages from the winter and to brand calves. Assigning a brand to a calf was generally not difficult because calves did not stray far from their mothers. "Maverick" calves, whose mothers presumably died over the winter, were sold at an auction to those participating in the roundup. ${ }^{49}$ During the spring and summer, cattle grazed and gained weight making them ready for the market in the fall, which necessitated another roundup. In principle each rancher could perform his own roundup but this had several problems. If a rancher performed his own roundup then he could steal the cattle of other ranchers whereas if all ranchers on the range participated in the roundup stealing was curbed. Moreover, a common roundup had two overarching advantages. A roundup was very labor intensive and there were economies of scale in having one roundup rather than several. The roundup was also stressful on the cattle that had to be herded together; and this disturbed their grazing. In short, a roundup made obvious economic sense.

The initial issue facing an association was: who was in and who was out. To be a member of a cattlemen's association you had to have a range right. A rancher could gain a range right through several methods. The first rancher in the area acquired rights through "first possession" which was a well

\footnotetext{
${ }^{48}$ Demsetz (1967) argued that property rights would spontaneously emerge to limit dissipation but this minimizes the collective action problem.

${ }^{49}$ In later years, maverick calves were used to help fund the large Wyoming Stockgrower's Association.
} 
respected norm. ${ }^{50}$ Alternatively, ranchers could homestead some land under the provisions of the Homestead Act of 1862 which allowed the claimant title to 160 acres, if he resided on the land and cultivated it for five years. A rancher could also file for a pre-emption claim which meant that he had the right to purchase 160 acres at $\$ 1.25$ /acre when the government decided to put the land up for auction at some future date. Land containing water was worth $\$ 1.25 /$ acre and many ranchers opted for this avenue. Many ranchers also filed for land under the auspices of the Timber Acts (1873 and 1878) and Desert Land Act (1879). ${ }^{51}$

After formation, one of the first issues confronting a Cattlemen's Association was to exclude outsiders, which associations tried to do before overstocking occurred in order to capture rents. This was accomplished by posting that the range was closed, generally through an announcement in a newspaper and not allowing an entrant to participate in the collective roundup. Dennen (1976) provides a succinct example of an association that perhaps acted to late. The Helena Montana Daily Herald of September 3, 1883 published the following notice:

We the undersigned, stock growers of the above described range, hereby give notice that we consider the said range already overstocked: therefore we positively decline allowing any outside parties or any parties locating herds upon this range the use of our corrals, nor will they be permitted to join us in any roundup on said range from and after this date. Dennen, 1976: 427

Preventing entry from outside cattlemen appears to have been reasonably successful until the rise in cattle prices in the early 1880 s along with the passage of new land laws in the late 1870s: the Timber Culture Act(s) and Desert Land Act. The Timber Culture Act allowed a claimant an additional 160 acres to a homestead provided that he plant trees on $1 / 4$ of the land. This was subsequently amended in 1878 to require the planting of only $1 / 16^{\text {th }}$ of the lot. The idea behind the Timber Act was again to benefit farmers. As Osgood(1929: 194 notes:

Congress was made to believe that if the western farmer were wheedled into planting enough trees, rainfall would be increased to such an extent that the arid West would succumb to the allconquering farmers,... Rain-making by legislative fiat was something new, even in the varied history of public land legislation.

In a similar vein the Desert Land Act was meant to help farmers, though the terms were stringent for farmers. A farmer could purchase 640 acres for $\$ 1.25$ /acre provided that he irrigated the entire plot

\footnotetext{
${ }^{50}$ It appears as if first possession as a norm for allocating rights works well when scarcity is not high - the region J$\mathrm{K}$ in Figure 2. For an excellent analysis of the political economy of the use of first possession in the U.S. Midwest see Kanazawa, Mark T. (1996). For the general use of first possession to allocate property rights see Lueck (2003) and Libecap (2007).

${ }^{51}$ We will discuss the filings under these acts in more detail later because by the 1880 s there were a significant number of allegations that cattlemen, particularly large eastern cattle companies, were abusing the spirit of these acts by having their ranch hands file for claims which they consolidated into large holdings.
} 
within three years. Regardless of the intent of the laws, very few farmers filed claims under the new land laws. Rather, the new laws enabled cattlemen to secure de jure property rights.

These new acts along with the existing provisions of the Homestead Act and pre-emption act enabled large corporate interests to move onto some existing ranges by filing for a de jure property right. The filings were fraudulent in both the spirit of the law (designed for agriculturalists) and letter of the law (there were no attempts to comply and no enforcement by the General Land Office). High prices for cattle along with the ability to acquire land through the various land acts led to a bovine boom beginning around 1880 , with yearly average monthly prices peaking in $1884 .^{52}$

Dale and Osgood capture the spirit of the boom:

The desire to engage in ranching became almost a craze. Prominent lawyers, bankers and other business men throughout the East began the formation of cattle companies in order to take advantage of the wonderful opportunities pointed out to them. Every great city in the East had men interested either directly or indirectly in ranching. Boston, New York, Philadelphia, and Washington, together with many lesser cities, all had a number of prominent men who invested money in ranching enterprises... Members of Congress and Senators or former Senators...invested large sums of money in the cattle industry (Dale, 1960: 81)

During the eighties, when the scramble to stock the ranges was at its height, the process was reversed and cattle moved westward in increasing numbers. Feeders found it more profitable to sell to the western cattleman at the high prices then prevailing, than to buy stock cattle to fatten for the market. Eastern stock, commonly known on the ranges as 'pilgrims,' 'states' cattle,' or 'barnyard stock' were crowded into the western-bound stock trains. In 1882-1884, there were as many cattle shipped west as east (Osgood, 1929: 91-93).

The result of the boom was a mixture of de facto and de jure property rights held by many of the original entrants who formed cattlemen's associations and de jure property rights held by many of the larger scale corporations. To protect their "rights" both groups turned to fencing: "Cattlemen were accused of setting up small barbed-wire kingdoms to the great detriment of the sturdy pioneer looking for land"(Osgood, 1929: 193). Fencing did deter entry though members of the range still had to limit overstocking on their ranges. At this stage property rights on the Great Plains were a mixture of second party specification/second party enforcement, and third party government specification with self and second party enforcement.

\footnotetext{
${ }^{52}$ The mean monthly highest price of steers per $100 \mathrm{lbs}$ in Chicago increased from $\$ 4.42$ in 1879; to $\$ 4.75$ in 1880; peaking at $\$ 7.52$ in 1882 . The average yearly high occurred in 1884 . The high in 1885 came in January at $\$ 5.15$ and declined over the course of the year to end at $\$ 4.66$. Prices hit their minimum for 1880 s in July of 1889 at $\$ 2.94$, recovering marginally afterwards, but not rising substantially until the turn of the 20th century (NBER 2009)
} 
On corporate ranges, the costs of overstocking were internalized but this was not the case for ranges operated by Cattlemen's associations. ${ }^{53}$ After preventing entry to limit overgrazing, the occupants of the range had to prevent two externalities: 1) because bulls were used for impregnating cows, ranchers would have an incentive to put cows and steers on the range but not bulls. Moreover, it mattered to all that the quality of the bulls was high; and 2) the total number of cattle on the range had to be limited to prevent overgrazing, which could result in cows having insufficient weight to withstand the winter. The By-Laws of the Little Missouri River Stockmen's Association provided a clause stipulating the bull to cow ratio:

It is the sense of this Association, and is hereby made binding on its members, that any man who shall hereafter turn out any female neat cattle upon the range shall place with them, at the time of the turning loose not less than seven (7) serviceable bulls for every one hundred (100) head of female cattle which are two years old and upward at that time; ...Proved violation of the above rule shall be deemed a proper subject for the complaint, the penalty to be decided by a majority of the Association present at the next meeting (Mattison 1950: 203)

Limiting overstocking on all ranges was difficult because to a certain extent it was an ex-post problem in that, if ranchers expected high prices or a mild winter then collectively you would want to stock more cattle than if ranchers expected a harsh winter. ${ }^{54}$ In any event a procedure needed to be adopted to ensure overstocking relative to other members. On many ranges, the number of cattle that one could graze would be in proportion to water rights which were acquired through first possession, pre-emption claims, or homesteading. The ability of cattlemen's associations to prevent overstocking is mixed but the evidence is clear that in most cases the Cattlemen's associations produced rents over the condition of open access. Evidence consistent with the production of rents was the monetary exchange of range rights:

The agreements regarding such matters as the partition of the range and use of water became property rights and were frequently bought and sold as land is sold today. Once a man's range rights were determined, they were respected by all (Yost 1966: 129; quoted from Dennen 1976: 434).

Dennen (1976: 434) gives evidence of two transactions of range rights. Exclusive of the value of the cattle and land, Dennen estimates the value of range rights for two ranches and found that the value reached $\$ 200,000$ for the sale of range rights on one ranch at the peak of prices in 1884 . Dennen also found that some ranches carried range rights on their accounting books as a positive asset.

\footnotetext{
${ }^{53}$ At the height of the cattle boom in the mid-1880s all ranges seem to be overstocked because of ex-post overly optimistic weather and price expectations.

${ }^{54}$ Recent work in behavioral economics, borrowing from psychology and sociology, shows that humans, especially males, tend to be ex-post too optimistic.
} 
An implication that the commons arrangements are effective is that cattle on such ranges should be fatter because of preventing overstocking. Cattle can live off their fat for a period of time which means that in severe winters, the loss rates should be less on ranges with effective Cattlemen's Associations. The widespread horrific winter of 1886-1887 in the West provides us with a natural experiment:

Blizzards struck in the middle of November and continued. The snow, although melting and freezing, piled higher and higher. By January the ravines and coulees were almost level with snow. The snow lay for several feet on the plateaus and river bottoms - too deep for the cattle to get through to the grass. ...During February, March and April, there was considerable speculation among the cattlemen as to what their losses would be (Mattison 1950: 190).

In his archival research Dennen (1976) found that loss rates varied considerably across ranges in large part not due to variation in weather but rather due to the effectiveness of organizations to limit entry and prevent overgrazing. The loss rates in Montana ranged from $10 \%$ to $90 \%$ depending mostly on the degree of overstocking (Dennen, 1976: 432). Some overstocking was due to the inability to prevent open access, particularly along routes for cattle drives. On other ranges, the differences in stocking could be due to different expectations of weather or prices. ${ }^{55}$ The losses for the ineffective Little Missouri Stockmen's association were so high that the members did not hold a general roundup in the spring of 1887 but waited until July (Mattison, 1950:191, quoting from the Dickinson Press, April 23, 1887). ${ }^{56}$

The 1880 s was a pivotal decade for the fate of de facto and de jure property rights in the Great Plains. To understand why ranchers won the short run battle over the de facto use of land in the majority of the Great Plains we need to analyze the various roles played over time by special interests, the bureaucracy that oversaw the range land - the General Land Office- and Congress. We also need to understand the use of the various land laws in place: the Homestead Act (1862); The Timber Culture Acts (1873 and 1878); and The Desert Land Act (1877); as well as the proposals emerging from Powell's "Report on Arid Lands in the West" (1878) and the report from the Public Lands Commission (1880).

The first proposal to recognize the aridity of the High Plains emerged out of John Wesley Powell's "Report on Arid Lands in the West" to Congress in 1878. Powell saw the High Plains as suited for agriculture only to the extent that farmers worked together in a minimum group of nine to complete an

\footnotetext{
${ }^{55}$ To some extent human optimism may have played a role but uncertainty may also have added to ex-post overstocking. McCabe (2004) argues that for nomadic herds in present day Kenya and Tanzania that the optimal strategy for herders is to stock as much as possible and periodically suffer large losses because of the inability to predict droughts.

${ }^{56}$ The lack of a roundup in 1887 suggests that the Little Missouri range was overstocked and that the association was either overly optimistic or had a monitoring problem. As a footnote to a footnote: Teddy Roosevelt was a member of the Little Missouri Stockmen's Association and was its president for several years.
} 
irrigation project and upon its completion the farmers individually secured title to twenty acres. ${ }^{57}$ Powell envisioned most of the land in High Plains as suited for pastoralists but here too he proposed that ranchers band together, similar to the actual workings of Cattlemen's Associations. Powell proposed that nine or more ranchers could secure title to 2,650 acres, provided that they had access to water. Though Powell's proposals were embodied in two bills sent to Congress along with the Report, Congress viewed the proposals with suspicion and allegations of supporting land monopolists. ${ }^{58}$ Indeed the notion of such large plots was quite foreign to the majority of Congressmen east of the $100^{\text {th }}$ meridian (Libecap and Hansen, 2004). Perhaps ironically the cattlemen in associations did not support either Powell's Report or the various land laws. The early cattlemen seemed to be quite content with the commons arrangements in place, and they were reluctant to lease or purchase land outside of what they needed to establish a range right.

Shortly after Powell's report, Congress convened a Public Lands Commission to report on the overall disposal of the public domain and to offer some recommendations. The Public Lands Commission issued a series of reports. In an early report, the Commission proposed a repeal of the pre-emption laws and the Timber Act. The Commission also advocated the sale of grazing lands in the High Plains. They proposed a sliding price scale over time; beginning in 1881 at $\$ 1.25 /$ acre, decreasing to $\$ 1 /$ acre in 1886 , 75 cents in 1890 and eventually falling to 12.5 cents. In a subsequent report the Commission recommended leasing the public domain for grazing. Again, ranchers did not endorse either the selling of land or the leasing of land because they preferred their de facto property rights. In a short period of time, this would change. The Congressional reaction to the proposals of the Commission echoed their reaction to the recommendations of Powell: members of Congress for the most part disagreed with the unlimited sale of the public domain. On the minds of many members of Congress was the worry of the monopolization of land not only by the original cattlemen but moreover by the surge of new entrants forming cattle corporations. Allegedly many of the new entrants entered fraudulent claims under the various land acts in place:

Much of this land was taken up by fraudulent means under the provisions of various land laws. A 'cattle king' employed a number of men as herders called 'cowboys.' The herds of cattle were located on a good grassy plat of ground, probably along a stream, and each cowboy was expected and required to make a desert-land entry, a timber-culture entry, and possibly entries under homesteading and preemption. Technically speaking, it was possible under these laws for one person to take out as much as 1,280 acres...(Robbins, 1942: 251).

\footnotetext{
${ }^{57}$ Powell drew on the successful experience of the Mormons in Utah for this proposal.

${ }^{58}$ Also, a few authors mentioned a prevailing federalist (nationalist) sentiment in Congress with which Powell's report was totally at odds because Powell advocated local water control and other decentralized controls on ranges.
} 
Following 1880, the Pre-emption, Timber and Stone, Timber Culture, and Desert Land acts came in for much criticism, since it was apparent that, like the commutation clause of the Homestead Law, they lent themselves to abuse and fraud. In the eighties the movement was given a great impetus by the discovery of enormous frauds in which foreign corporations and titled noblemen were engaged for the purpose of building up vast estates (Gates, 1963: 338).

By the mid-1880s the ranchers who only five years earlier did not support proposals for the establishment of de jure property rights on the range, now led the movement for leasing the range. At the 1884 annual meeting of the National Cattle Growers' Association a member introduced a resolution encouraging Congress "to enact such laws as will enable the cattlemen of the West to acquire by lease the right to graze upon unoccupied lands." (quoted in Osgood 1929: 201.) Interestingly within the National Association, the Wyoming delegation which had been the most vocal in opposing the earlier recommendations of the Public Lands Commission were now the most vocal proponents of leasing. ${ }^{59}$ The appeals of the Cattlemen fell on deaf ears and Congress maintained the status quo. Despite the rhetoric for reform, retaining the status quo meant: retaining the de jure property right for homesteaders but without enforcement; de jure fraudulently acquired property rights for some ranchers; and de facto rights for the majority of ranchers.

Given the fact that the majority of the ranges were still under de facto property rights, one might have anticipated that there would be conflict between the homesteaders and the cattlemen. Indeed there was considerable potential conflict as soon as homesteaders covered their opportunity costs for moving to the Great Plains - point $k$ in Figure 2- beginning in the $1870 s .{ }^{60}$ Initially Homesteaders petitioned the General Land Office, their legislators and an in some instances appealed to the courts. For the most part we found that the majority view in the literature concurs that ranchers had a dominant violence potential and the federal government opted not to enforce the de jure rights of homesteaders:

59 Between 1860-1880, Texas supplied a great deal of the cattle demand generated by the growth of the industry in the Great Plains region. It may be no coincidence that the leasing idea took hold in the North after years of contact with Texas cattlemen, many of whom operated under a successful leasing system instituted through the autonomous land control Texas retained after joining the Union.

${ }^{60}$ Sheep herders also encroached on the land of cattlemen, reaching a climax in the first decade of the $20^{\text {th }}$ century as cattlemen were forced to move to higher elevations. Unlike the homesteaders, the sheep herders did not have a de jure right and as such the cattlemen felt less constraint in dealing with sheep herders over establishment of de facto rights. In addition, many of the sheep herders were Mormon and the general populace felt little sympathy for them. Clearly the violence potential of a cattlemen's association trumped the violence potential of a sheepherder. Sheepherders did not naturally band together for a roundup because sheep herds grazed alone and were tended. O'Neal (1989) documents 120 separate instances of conflict between ranchers and sheep herders with 50 deaths of sheep herders and their families and the slaughter of over 53,000 sheep. Ultimately, to avoid conflict, sheepherders migrated to land not as well suited to cattle; more rugged and at higher elevations. 
...his (the ranchers) control must be extra-legal and at times illegal. He might keep off other herds either by fencing the public land or by cooperation with his neighbours. His success in these methods of trying to solve the problem of maintaining his share of the free pasturage depended, on the one hand, on the negligence or impotence of the central government in the enforcement of the land laws, and on the other, on the sanctions of range customs backed, if necessary, by group force (Osgood, 1929: 116-117).

The homesteaders had resort to the courts but this was a costly and time consuming process. Moreover, in the heart of cattle country, e.g. the high plains in Wyoming and Montana, the cattlemen controlled the local legislatures and courts. This "home court" advantage is analogous to the situation in Australia described in the prior section. In the early 1880s homesteaders brave enough to settle in the areas dominated by the ranchers and foolhardy enough to bring cases to the judiciary, found that, if they were lucky, their cases would be dismissed but in some cases ranchers (or lawmen acting in the interests of the big operators) employed the tactic of accusing the homesteaders of cattle rustling. Indeed, the accusation of "rustler" was frequently used to intimidate homesteaders, many of whom kept a small herd of cattle for self-consumption as well as sale in order to complement the growing of crops. If convicted of "rustling" a homesteader would lose his livestock. A clearly biased law was passed in 1885 in Wyoming allowing inspectors of the Wyoming Stockgrower's Assocation to confiscate any cattle with "unknown brands" a.k.a. any cattle whose owner was not part of the association which had a monopoly on registering brands.

The cattlemen also resorted to intimidation and here, ranchers clearly had a violence potential over homesteaders. ${ }^{61}$ For this reason there was little actual conflict, particularly once it became clear that the executive branch would not enforce their rights:

By 1885 , the cattle interests were deliberately chasing settlers off their lands, enclosing vast areas and defending these enclosures with armed riders. ...Settlers avoided these localities as they would the plague (Robbins, 1942: 250-251).

Most of the means that the Cattle Barons used against the helpless invaders of their domains were effective. Interference from law enforcement authorities was seldom encountered. If range rights had no standing under law, they were recognized and respected by officers of the law and by local courts, and legislatures were seldom successful in overriding them, even though repeated attempts were made by a few misguided legislators who considered it their responsibility to serve the best interests of all their constituents (Terrell, 1972: 227).

\footnotetext{
${ }^{61}$ For ranchers this was $2^{\text {nd }}$ party specification and third party (hired hands) enforcement. Not all ranchers resorted to violence and over time the tide of homesteaders encroached on the territory of the ranchers but the tide did not swell in the heart of cattle country until the first decade of the 1900 s with the increase in the price of wheat as well as increased enforcement from local, state and federal governments.
} 
Yet, the General Land Office (GLO) did little to enforce the rights of homesteaders against ranchers. The reason for the inaction of the land office was twofold: the GLO was budget constrained and the large scale ranching corporations had significant clout in Congress - especially in the Senateand through the executive branch, which controlled the GLO. The GLO was under the control of the Interior Department. The Secretary of the Interior had nearly complete discretion over the appointment of the Commissioner of the General Land Office. Until the early 1880s the GLO condoned the informal claims of ranchers and did nothing about the "illegal fencing" of the public domain nor the alleged fraudulent claims under the land acts. During the term of Commissioner Noah McFarland (1881-1884) the GLO was flooded with letters from prospective homesteaders asking the GLO to intervene on their behalf. McFarland sent agents out west to determine the extent of illegal fencing and the GLO issued a report to Congress in 1884. Following the report of illegal fencing, newly elected President Grover Cleveland issued a proclamation in 1885 ordering the removal of all illegal fences. Congress followed by passing anti-fencing legislation in $1885 .^{62}$ Despite the Presidential and Congressional actions, there was little governmental enthusiasm for enforcing the illegal fencing law, particularly in the Senate.

Commissioner Sparks succeeded McFarland. Sparks was a zealously dedicated civil servant and advocate of homesteaders. In 1886 he authorized the printing of the names of ranchers who had illegal enclosures on public lands. Furthermore, he petitioned the War Department to take down the illegal fences in Wyoming. Sparks also went after the abusive use by ranchers of the land laws to capture de jure rights: he suspended final action on all land entries in Colorado, the Dakotas, Idaho, New Mexico, Utah, Washington and Wyoming, along with portions of Kansas, Minnesota and Nebraska. The suspended acreage tallied approximately 2,750,000 acres (Robbins, 1942: 293). In addition Sparks publicly advocated the abolition of the extant land laws except for the Homestead Act. Sparks went even further by advocating that Congress and the Executive limit the ability of land grant railroads to acquire additional acreage. Clearly, Sparks went too far and all the interested parties except homesteaders, besieged Congress to stop Sparks. The Senate introduced a bill to protect the extant entries that Sparks had frozen. Meanwhile, the War Department did not act on the request of Sparks to cut illegal fences. The situation was at a stalemate until the Secretary of the Interior essentially forced the resignation of Commissioner Sparks in November of 1887. The Secretary replaced Sparks with a new Commissioner who was more sympathetic to the interests of ranchers and railroads. By early 1888 the

\footnotetext{
${ }^{62}$ The House supported the interests of the Homesteaders steadfastly, while the Senate was more ambivalent. Many members of the Senate held interests in ranching operations in the West, though we do not know the total number of Senators. Part of their "interest" may have been simply bribes.
} 
Interior Department revoked the reform platform that was started by McFarland in the early 1880s and subsequently championed vigorously by Sparks.

The actions of Sparks and Congress did encourage new homestead entrants as well as increased entries by cattlemen under the existing land laws. ${ }^{63}$ In addition to the actions of the government, viewed as supportive by the homesteaders and threatening by the cattlemen, an additional reason for the increased migration of capital and labor to the frontier was the result of the horrific winter of 1886-1887 which decimated herds and prompted the failure of many corporations. Capital and labor moved to fill the vacuum. Naturally, the migrations led to more potential conflicts on the range, but by 1888 the General Land Office, and Congress opted to stay out of the battle on over rights. ${ }^{64}$

Though the federal government did not play a role in enforcing the de jure rights of homesteaders until the $20^{\text {th }}$ century, the gradual migration of homesteaders to the frontier in the late 1880 s led to an increase in local support for homesteaders by the press, the legislatures and Courts in the High Plains, particularly the eastern High Plains (Libecap and Hansen 2004). The change in the local political climate led to a secular decline in the use of intimidation by cattlemen because it was no longer effective because over time homesteaders could win in court to uphold their de jure rights. ${ }^{65}$

Congress amended land laws again in 1891 with the General Revision Act. The Act was quite sweeping in that it ended cash sales of land; repealed the pre-emption provisions; repealed the Timber Culture Acts; and placed additional restrictions on claiming land through the Desert Act. These changes prevented ranchers from formalizing their de facto claims but the laws did nothing to enforce the de jure claims of homesteaders. The GLO, continually budget constrained, did not engage in any antifencing activity until the Presidency of Teddy Roosevelt in 1901. As a result the informal commons

\footnotetext{
63 "The onslaught of the anti-monopolists had the effect of stimulating the speculators, cattlemen, lumber and mining companies to prompt action before the public domain should be closed to them. Land sales and entries under the Pre-emption, Timber Culture, Timber and Stone, and Desert Land acts and the cash sales system shot up to a high point in 1888..." (Gates,1963: 338).

${ }^{64}$ With its meager budget the GLO was in no position to enforce the rights of homesteaders. Congress held the purse strings, opting for rhetorical sympathy for homesteaders but inaction.

${ }^{65}$ We stress that we focused on conflict in the regions of the high plains where the cattlemen ruled supreme from the 1870 s until the turn of the $20^{\text {th }}$ century. In the more eastern regions of the high plains, e.g. Kansas, Nebraska and parts of the Dakotas, there were notably less instances of intimidation throughout the period. In these regions, activity was more mixed and higher value, with agriculture and ranching increasingly co-existing though the ranching became more specialized, e.g. selective breeding and the ranchers possessed de jure rights. The differences between the lands occupied by the Cattle "barons" (Wyoming and Montana) and the mixed systems stemmed from the lack of hegemony of the cattlemen in the less arid more easterly regions of the high plains. From the "get go" the local politicians in more eastern areas fostered migration and championed the notion of "rain following the plow." This interpretation is consistent with the narrative of Libecap and Hansen (2004) who argue that politicians over time viewed the larger voting bloc of homesteaders as their constituents.
} 
arrangements of ranchers continued into the $20^{\text {th }}$ century and were eventually replaced with government leases. ${ }^{66}$

Roosevelt, who was a prior rancher, though one who suffered considerable losses throughout his years of ranching from the 1880s until the end of the century, sent out the cavalry in 1901 to enforce the de jure rights of homesteaders. The first years of Roosevelt's presidency reflect his conservationist fervor as well as his anti-monopoly views: "Roosevelt had very positive views about the need for firm executive control over the nations use of natural resources...Roosevelt vigorously prosecuted lumbermen, ranchers, miners and power companies that ignored the law " (Watson, 1976: 127-128). As a result Roosevelt wanted to protect the government lands from the large ranching interests turning their de facto rights into de jure rights. Much of the de facto lands Roosevelt wanted to maintain as National Forest lands. Roosevelt put the ranchers under increased scrutiny due to his belief that speculative land interests and monopolists had exploited remaining loopholes and oversights in GLO policy. Roosevelt's actions in cutting down illegal fencing resulted in a rapid increase in the number of homesteads filed in the Great Plains states. ${ }^{67}$ The increased settlement by homesteaders in the early $20^{\text {th }}$ century prompted the movement of ranching activities onto more arid land in the West. Again there was little actual conflict because in a show of force between the Cavalry and ranchers, the Cavalry would win hands down so ranchers opted to move their livestock rather than fight. Throughout the period of the open range, circa 1870 to 1900 , we found only scattered evidence of conflict resulting in violence because the outcome was generally certain. The collective arrangements of ranchers into Cattlemen's Associations, (and individual large corporate claims) prevented entry onto ranges designated as closed because a potential ranching entrant did not stand a chance against a group of ranchers. Similarly prospective homesteaders unless backed by the coercive power of state would lose in a violent conflict against ranchers. Eventually, when homesteaders increased sufficiently to have their voices and rights upheld by local governments, and the federal government finally acted to enforce de jure property rights against the de facto property rights of ranchers, the ranchers backed down and allowed homesteaders in. The saga of the open range demonstrates the interplay of de facto versus de jure property rights and important role of politics intermediating the two.

\footnotetext{
${ }^{66}$ These leases were preceded by a significant amount of study and debate concerning leases. A portion of the Public Lands Commission Report in 1915 included a study by Coville of the leasing system prevalent in Texas since the mid- $19^{\text {th }}$ century.

${ }^{67}$ We note that not all of the increased settlement was the result of the activities of Roosevelt. Wheat prices boomed in the early $20^{\text {th }}$ century before declining dramatically in 1920 (Alston, 1983).
} 


\section{Settlement of the Brazilian frontier}

In 1822, a few weeks before achieving independence from Portugal, the Emperor of Brazil suspended the use of sesmarias (large land grants), the main formal means through which land had been granted since the $16^{\text {th }}$ century, leaving no land law in its place. Over the previous centuries the colony's economy had been through a sugar cycle (1550-1650) and a gold cycle (1700-1780) both predominantly based on slave labor. Although the formal route for access to land had been the sesmarias, which were free and readily available to those who owned slaves, land was not scarce and so could easily be squatted on. The suspension of the sesmarias was partly a reflection of the abundance of land, particularly in a period (early $19^{\text {th }}$ century) when economic activity was at an all time low (Furtado, 1959). From 1822 to 1850 there were no formal rules regarding the access and use of land and the issue was not even mentioned in the new country's constitution of 1824. After the 1830s, however, the economic viability of coffee started to improve and plantations quickly started to spread, first in the region of Rio de Janeiro and then gradually expanding the frontier south towards São Paulo and eventually westward in the São Paulo interior.

This process of frontier expansion conforms to the dynamics of our model in Section II yet with some idiosyncrasies given the details of the Brazilian economy in the period when the scarcity of land started to kick in. The early entrants were large slave owners (referred to as capital in Section II). ${ }^{68}$ Initially landowners imported slaves to use during the sugar and gold booms but these had been underutilized since the end of the gold cycle in 1780 given the stagnant economy. The slave/landowners were thus willing to engage in the production of coffee even before coffee prices, as well as those of other commodities, started to rise after the 1840s. In a sense the landowners were already on the frontier, though they may not have moved to the frontier given the new relative prices after the sugar and gold booms ended. There were very few small landowners because the Brazilian economy up to that point had offered little return for smallholders who could not afford slaves. Few immigrants were willing to go to Brazil while slavery and large plantations were the norm. ${ }^{69}$ In this period there was consequently first person specification and self-enforcement, which due to low scarcity was easily achieved.

\footnotetext{
${ }^{68}$ Though coffee requires a lot of labor, initially coffee cultivation was performed by slaves, a capital asset from the owners' viewpoint. In addition coffee is between a tree and perennial shrub, lending it more to designation of capital intensive. The relative applications of labor or capital do not affect our analysis of settlement.

${ }^{69}$ It remains as puzzle as to why more immigrants did not migrate to the South of Brazil where the return to selfsufficient farming appeared to be higher than the return that prospective immigrants reaped in Portugal or in many other countries. If it was a capital constraint, what prevented an indenture market from arising?
} 
As the NPV to land started to rise with the prospect of higher coffee prices and the diffusion of the habit of drinking coffee throughout the world, the demand for land increased leading to a rapidly expanding frontier. With higher NPVs competition for the land increased and two separate problems emerged for the coffee producers. The first problem is that in the absence of any de jure rule for allocating land the de facto reality had been massive levels of squatting by large landowners covering huge expanses of land that were not actually occupied or used, given the low level of economic activities that had prevailed following the end of the gold cycle. Claims overlapped but this did not lead to conflict while land was beyond the economic frontier -the point that would induce migration. ${ }^{70}$ With the rise in NPVs, however, and the prospect of imminent higher returns even from land still beyond the frontier, conflicts erupted, both physical and legal as competing claimants tried to make their claims prevail. Dean (1971: 611) states that during this period "...the landowners hired gunmen killed not only recalcitrant backwoods 'intruders', but also other landowners." Similarly Osório Silva (1996: 133) notes that "... litigation and disputes over boundaries were in the order of the day, being responsible for a great part of the fights among families and crimes in the interior." The need to hire gunmen and lawyers marks a shift to third party enforcement, while specification was still first party. The costs and rent dissipation generated by such conflicts was one of the sources of a rising demand for formal property rights to land by mid- $19^{\text {th }}$ century.

A separate issue which also fueled the demand for a new land law at this time was the pressure by the English for the end of slavery. Brazil had managed to evade earlier attempts by the British to impose this prohibition, but by mid-century it was becoming obvious that the importation of slaves would have to cease in the near future and complete abolition would eventually follow. As coffee production was completely based on slave labor and large plantations, this situation required that a new source of labor, European immigration, be set up to allow a smooth transition. Doing so, however, involved establishing a land law that would assure that the immigrant labor would effectively be directed towards the plantations rather that moving to the frontier to squat on land of their own. Landowners needed to eliminate the availability of free land if they were to retain their privileged position. ${ }^{71}$ In other words there was a need to move to third party specification.

\footnotetext{
${ }^{70}$ A similar situation occurred in the Amazon in the $20^{\text {th }}$ century following the collapse of the rubber boom in the early part of the $20^{\text {th }}$ century until the encouragement by government of new entrants in the 1960s and 1970s.

${ }^{71}$ This is a recommendation that had already been made in the Australian context by $19^{\text {th }}$ century British economist E.G. Wakefield, who was often cited in the parliamentary debates throughout the 1840s in Brazil when this issue has hotly debated (Dean, 1971: 613; Osório Silva, 1996: 99; Carvalho, 1988: 86).
} 
In 1850 a new land law (Lei de Terras $N^{\circ}$ 601) was finally approved and in that same year the transatlantic slave trade officially and effectively ceased. The law had two main provisions: 1) validation with no restrictions on all land claims obtained prior to 1850, whether from sesmarias or plain squatting; and 2) purchase was the only legal means of securing additional land. Given that Parliament essentially represented the landed elite the validation of squatting was not contentious. ${ }^{72}$ The second measure was less consensual as the landowners in frontier São Paulo regions (represented by the Liberal party) faced plenty of land to be appropriated in the future, while the landowners in the closed Rio de Janeiro frontier (represented by the Conservative party and closer to Emperor) did not have such opportunities. The first pass at approving the law in the early 1840s was blocked by the Liberals coming to power, but upon the Conservative return in 1850 the law was approved imposing the restriction on further squatting. As we shall see the consolidation of the frontier landowners' power in the second half of the $19^{\text {th }}$ century implied that this restriction was not enforced and land was continuously squatted for decades to come. The inability of the central government to apply the law meant that specification remained in first party hands. The de jure stipulation of purchase would come to play an instrumental role in impeding the access to land by immigrant laborers after abolition of slavery in 1888 . At that point enforcement and specification would be done by the state governments, but were used primarily in favor of the landowning oligarchies and to stop immigrant labor from having access to land.

The framework in Figure 1 helps to understand the situation described above. The ideal situation for the landowners would have been a continuation of slavery and a land law that did not restrict their expansion into the frontier but simply arbitrated the conflicts among themselves inherent in that expansion. Such a scenario would yield returns along the upper envelope of the NPV curves, $A B C D$. For the landowners this would be the equivalent of the secure property rights situation. The property rights could even be merely de facto as they would be secure because there are no immigrant laborers to compete for land. But with the end of slavery that scenario was no longer available. The alternatives depended on finding a way to successfully substitute immigrants for slaves. If a change in property rights did not emerge that promoted immigration yet kept the immigrants from seeking their own land, then the NPV faced by the landowners would be the lower returns GLCD. From the perspective of the landowners this can be thought of as the open access situation with free entrance and dissipated rents. If, however, the land law of 1850 achieved its purpose of forcing immigrants to sell

\footnotetext{
${ }^{72}$ Even by the end of the Empire in 1888 only $1.5 \%$ of the population had the right to vote. The franchise was limited to men over 25 with "means." The electorate voted for an electoral college of sorts which then chose the deputies. The emperor chose the senators. Over time power tilted in favor of the landowners in Sao Paulo region and their political representatives
} 
their labor for several years before being able to purchase their own land, the return to the plantation owners would be above the open access situation and below the secure (de facto) property rights situation. This would be a return along $F B C D$ in Figure 2. We can think of the new land law as a commons arrangement in the sense that the importation of immigrants and their containment as laborers rather than owners was a collective good with severe free-rider problems. In effect this is the outcome that prevailed once slavery was abolished. Although the higher NPVs associated with slavery were no longer attainable, a second-best (from the point of view of the landowners) was achieved through massive immigration, with the free-rider problem solved by having the central and state governments finance and coordinate the immigration process. ${ }^{73}$

Immigration did not increase all that dramatically immediately after the passage of the 1850 Land Law. Although the importation of slaves had been forbidden it was clear to landowners that the use of the stock of slaves could be maintained for several decades yet. Given the high returns to coffee production under slavery, the law was not enforced and the frontier continued expanding through further squatting on the frontier. The law required that all landowners demarcate and register their properties so that the State, in principle, could sell the remaining land. In practice landowners did not register their land and either claimed that any subsequent encroachments had been squatted on prior to 1850 , and were thus legitimized by the Land Law, or were able to lobby successfully for ever later years as the benchmark for legitimate claims, thus maintaining.

Carvalho (1988: 94) provides a detailed account of how the landowners evaded and ignored all the restrictions from the Land Law that were contrary to their interest. The sale of land, which, according to the Law of 1850, was supposed to finance the immigration effort, was insignificant and when the pressure for the abolition of slavery increased in the 1880 s the government had to turn instead to the general budget. The capture of government by landowners intensified after 1889 when Brazil became a republic and state governments received significant power and autonomy. ${ }^{74}$ Most states

\footnotetext{
${ }^{73}$ From 1892 to 1930 the revenue from coffee export tax was 50\% of the total tax revenue in São Paulo. During this period the expenditures on immigration programs were on average $5.2 \%$ of the total tax revenue and $10.5 \%$ of coffee tax revenue (data from Holloway, 1980). Therefore it is not the case that the coffee producers were mostly paying for the immigration themselves. According to Carvalho (1988: 100): "Immigration was financed with budgetary resources that subsidized transportation, immigration and colonization companies, as well as farmers and immigrants. The costs were socialized not only among the farmers, but among the taxpaying population through the public budget, both at the central and at the provincial levels."

${ }^{74}$ The coffee planters in the São Paulo frontier were major players in the overthrow of the Brazilian throne, together with parts of the army and the urban middle class (Viotti da Costa, 1985). The discontent of planters arose from both the abolition of slavery and the restriction which the Land Law tried to impose on their ability to incorporate new land.
} 
adopted land legislation that essentially replicated the 1850 Land Law. Although in de jure terms this legislation prohibited further incorporation of land to the private domain through squatting, in practice “... the fundamental characteristic of the legislation approved by the states was the liberality towards the (large) squatters" (Osório Silva, 1996: 255.) It was actually convenient for the local oligarchies to have the law in place for selective use to keep others from access to land. This period can thus be interpreted as a switch to third party specification and enforcement.

By the time that the maintenance of slavery was no longer politically sustainable in the $1880 \mathrm{~s}$, the importation of immigrant labor had been effectively organized and the abolition of slavery in 1888 and transition to free labor came about with few tribulations for the coffee planters apart from the unavoidable move to a second-best form of labor. The flow of immigrants in the subsequent decades, especially in São Paulo, the main coffee region, guaranteed a steady availability of labor at low wages (Bazanezi et al., 2008: 92; Hall, 1969; Halloway, 1980). ${ }^{75}$ The period after the proclamation of the republic in 1889 up to 1930 would be the golden age of coffee with ever-expanding planted area and prices kept high by government intervention despite systematic over-production. It is in this period that the landowners faced the biggest threat of entry of immigrant laborers who could potentially squat on marginal land prior to the arrival of the coffee capitalists.

In the Brazilian case the political equilibrium was clearly skewed towards the landowners and the laborers stood very little chance of winning any dispute for land, whether physical or political. Local oligarchies dominated access to land and power in their regions, usually through the figure of the allpowerful coronel that presided with feudal-like rights and reigned through a mixture of paternalism and violence, strengthened by his association to central state politicians to whom he could deliver votes. ${ }^{76}$ Laborers typically lived and worked on large plantations and were even given the right to plant for their

\footnotetext{
${ }^{75}$ Rivera, Nugent and Saddi (2004) argued that land laws evolved through the 1850-1920 period in a way that made property rights more secure as a means to encourage immigration. They create an index of the precision of the law that varies over time and use this in a first-order vector autoregression specification, where the other dependent variable is the annual flow of immigration and the explanatory variables are coffee exports, terms of trade and presence of slaves (dummy). In the equation where the flow of immigrants is the dependent variable they are surprised to find that the lagged total precision of the law has a negative effect on immigration as their story predicted a positive relation. Their result is however perfectly compatible with our analysis where coffee planters use their clout, including politically through the law, to deny access to land for immigrants and other potential smallholders.

${ }^{76}$ The key to the power of the coronels was the control of the franchise which was not secret. Universal literate male suffrage existed which gave the franchise over time to $6 \%$ by the 1920 s. Despite the stipulation of literacy coronels could deliver the votes of their workers. Workers exchanged their votes as part of the paternalistic package offered by the coronels. Many aspects of the rural paternalistic system are similar to what prevailed in the U.S. on large plantations from the 1890s until the mechanization of cotton in the 1960s (Alston and Ferrie, 1993).
} 
own use, but access to land ownership was rarely a possibility. Even if one managed to squat on land in marginal frontier areas, it would typically be difficult to retain the land once the coffee frontier arrived and competing claims (often with questionable titles) by the large landowners emerged (Osório Silva, 1996: 336). Thus in Brazil the 'coronels' effectively preempted the entrants (in Figure 2) and the coffee planters retained strong de jure and even stronger de facto rights bolstered by their political dominance. ${ }^{77}$ This process was not devoid of violent conflict, not only against potential small entrants, but between the different oligarchy/families that disputed not only land but control of municipal power. According to Osório Silva (1996: 263 ):

... the benevolence of the state's land policies towards the squatters did not imply a democratization of the access to land. ... The essential condition for a squatter to become an owner was to stay on the land that is to be legalized for a sufficiently long time. To stay on the land does not necessarily mean to cultivate it, but rather to stop others from squatting on it and/or avoid being removed from the land by the municipal and state authorities in charge of the public patrimony, who acted with scandalous impartiality. To stay on the land the large farmer/squatter counted on his own resources (armed henchmen) and sought to stay well connected with the state authorities. ... Thus in the long run the little vigilance that the small squatters could muster to try to stay on the land was useless. Their permanence on the land was temporary and unstable; lasting only until stronger forces showed up to kick them out. Osório Silva, 1996: 336-337.

After 1930 Brazil initiated in earnest its industrialization process and a shift of power from rural to urban elites started to take place. By then the extremely concentrated land ownership structure was consolidated. The process of frontier expansion from that time has followed a similar pattern, where land is titled long before it is occupied. The peasants that initially occupy the land are the first stage through which the frontier expands. They are subsequently replaced by large landowners in a process that Foweraker (1981: 10) notes is mediated by law, the bureaucracy and possibly violence.

The slowness and bias of the legal system, and the very concept of 'ownership 'of land work against the peasant on the frontier. Legal right to land always belongs with others, and their own 'legal' claims and protests are always invalidated by the mysterious language of the law and bureaucracy. ... (W)here the provisions of the law are incomplete or insufficient, then violence is used to force the peasants from the land, or sever their surplus from them.

(Foweraker, 1981: 117)

Only in the 1990s, with the rise of the Landless Peasants Movement (MST), did landless peasants begin to master this 'mysterious language' and start to use the law and bureaucracy to

\footnotetext{
${ }^{77}$ Note that although there are not significant economies of scale for growing coffee, the pattern of production was overwhelmingly on large farms. This is evidence of the greater importance of politics as a determinant of property rights rather than endowments being the primary determinant as in Engerman and Sokoloff (1997). We thank Stephen Haber for pointing this out.
} 
achieve access to land through land reform (see Alston, Libecap and Mueller, 1999a,b, 2000, 2008).

\section{Concluding Remarks}

In our analytical framework there is a progression of settlement: from squatters, with selfenforcement; to de facto commons arrangements; and ultimately to de jure titled land. In the Australia and the U.S. case studies, the government intervened to encourage premature or inappropriate settlement which led to either actual conflict or the potential for conflict. In the Brazilian case the absence of any specified de jure property rights by the government enforcement led to de facto selfenforced and third party enforced claims, along with sporadic conflicts. The Australian case exhibited the least actual conflict between the heterogeneously endowed settlers, the squatters who moved to the frontier to graze sheep and the selectors who moved to take up agriculture because of government policies. Little conflict emerged because by the time of the migration of the selectors, the squatters were wealthy and politically connected and thereby better able to evade the law on limiting acreage. Moreover, the rental stream from the land was higher for grazing than settled agriculture so over time squatters could out-compete the agriculturalists for the land. The U.S. case had a high potential for conflict but little conflict transpired because of the disproportionate violence advantage of ranchers over homesteaders. Ranchers moved to the frontier first and progressed from informal claimants, with norms, to more organized cattlemen's associations. Homesteaders subsequently attempted to settle on the land held informally by ranchers but the ranchers through threats of violence dissuaded many potential homesteaders from filing claims. Instead the homesteaders took their grievances to the political arena though it took the government over twenty years to enforce their de jure rights. Once the U.S. cavalry came to the aid of homesteaders, ranchers backed down. The Brazilian case also had a high potential for conflict with immigrants but with little conflict actually occurring. Large coffee plantation owners harnessed their political power to prevent competition over land claims persuading the central and state governments to deny immigrants access to land. The violence advantage of local coronels reinforced their political power. In turn, this reduced the potential and actual conflict that may have occurred between the coronels and the immigrants. Nevertheless, conflict did erupt periodically among the large coffee planters.

The establishment of norms by all original settlers in Australia and the U.S. shared certain characteristics: 1) The settlers limited the size of claims (or the number of sheep or cattle allowed to graze); 2) the claimants agreed to uphold the claims of others; 3 ) the claimants at some point banded 
together to exclude outsiders; and 4) the claimants petitioned the government for formal recognition and enforcement of their claims as scarcity values increased. In Brazil because of the huge gains to claimants from securing land through violence and the absence for many years of any access to de jure rights, the large planters only acted collectively in the political arena to exclude outsiders (immigrants), and to legitimate their squatted claims.

In all three cases, the political power of the first claimants influenced the supply of formal property rights to their claims. In the Australian and US cases, where this political power was relatively diluted by the extensive franchise, the supply of de jure rights was not in their favor. However, a lack of enforcement of de jure rights for entrants resulted in incumbents being able to prevent the initial reallocation attempts by utilizing either a wealth and/or violence advantage. In Brazil the wealth and political advantage of the initial claimants was overwhelmingly stronger than the potential entrants. Our cases suggest that de facto rights tend to prevail for a time even in the presence of de jure rights that fail to support them because of the lack of political will to enforce de jure rights. Generally, the supply of formal rights to land will be associated with rent dissipation if formal rights do not recognize the status quo de facto rights. Rent dissipation took the forms of land use inconsistent with relative prices, political lobbying, violence and threats of violence. 


\section{References}

Acemoglu, Daron and James A. Robinson. 2006. Economic Origins of Dictatorships and Democracies. New York: Cambridge University Press.

Acheson, James M. 1987. "The Lobster Fiefs Revisited: Economic and Ecological Effects of Terrioriality in the Maine Lobster Industry," in The Question of the Commons: The Culture and Ecology of Communal Resources. Edited by Bonnie J. McCay and James M. Acheson.

Adeney, William. 1845-1847. Awards and Correspondence. MS 11920. State Library of Victoria.

Allen, Douglas W. 2002. "The Rhino's Horn: Incomplete Property Rights and the Optimal Value of an Asset" Journal of Legal Studies, 31 (June): S359-S358.

Almeida, Ana .L.O. 1992. The Colonization of the Amazon. University of Texas Press.

Alston, Lee J. 1983. "Farm Foreclosures in the United States During the Interwar Period," Journal of Economic History, 43, December: 885-903.

Alston, Lee J. and Joseph P. Ferrie. 1993. "Paternalism in Agricultural Labor Contracts in the U.S. South: Implications for the Growth of the Welfare State," American Economic Review (September): 852876.

Alston, Lee J., Thráinn Eggertsson and Douglass C. North, eds. 1996. Empirical Studies in Institutional Change, Cambridge University Press.

Alston, Lee J., Edwyna Harris \& Bernardo Mueller, (forthcoming) 'Property Rights, Land Settlement and Land Conflict on Frontiers: Evidence from Australia, Brazil and the U.S.', In Research Handbook on the Economics of Property Law (Kenneth Ayotte \& Henry E. Smith, eds., Edward Elgar).

Alston, Lee J., Gary. D. Libecap and Bernardo Mueller. 1998. "Property Rights and Land Conflict: A Comparison of the U.S. Western and Brazilian Amazon Frontiers" in Latin America and the World Economy Since 1800. Edited by Coatsworth, John H. and Alan M. Taylor. Cambridge: Harvard University Press: 55-85.

Alston, Lee J., Gary. D. Libecap and Bernardo Mueller. 1999a. "A model of rural conflict: Violence and land reform policy in Brazil." Environment and Development Economics 4: pp. 135-160.

Alston, Lee J., Gary. D. Libecap and Bernardo Mueller. 1999b. Titles, Conflict, and Land Use: The Development of Property Rights and Land Reform on the Brazilian Amazon Frontier.

Ann Arbor, The University of Michigan Press.

Alston, Lee J., Gary. D. Libecap and Bernardo Mueller. 2000. "Land Reform Policies : The Sources of Violent Conflict, and Implications for Deforestation in the Brazilian Amazon." Journal of Environmental Economics and Management, 39:2, pp. 162-188.

Alston, Lee J., Gary. D. Libecap and Bernardo Mueller. 2008. "Interest Groups, Information Manipulation and Public Policy: The Landless Peasants Movement in Brazil." Working Paper. University of Colorado.

Alston, Lee J. and Bernardo Mueller. 2004. "Property Rights and the State." in Claude Menard and Mary M. Shirley, eds. Handbook for New Institutional Economics, Norwell MA: Kluwer Academic Publishers.

Alston, Lee J., Gary D. Libecap and Robert Schnieder. 1996. "The Determinants and Impact of Property Rights: Land Titles on the Brazilian Frontier" Journal of Law Economics and Organization 12, pp. 25-61.

Anderson, Terry L., and Peter J. Hill. 1975. "The Evolution of Property Rights: A Study of the American West" Journal of Law and Economics, 18:1, pp. 163-179.

Anderson, Terry L., and Peter J. Hill. 1990. "The Race for Property Rights" Journal of Law and Economics, 33 (April): pp. 177-197.

Anderson, Terry L., and Peter J. Hill. 2002. "Cowboys and Contracts" Journal of Legal Studies, 31 (June): S489-S514. 
Anderson Terry L., and Peter J. Hill. 2004. The not so Wild, Wild West: Property Rights on the Frontier, Stanford University Press.

Anderson, Terry L. and Fred S. McChesney. 1994. "Raid or Trade? An Economic Model of Indian-White Relations. Journal of Law and Economics, 37:1, pp. 39-74.

Anderson, Terry L. and Fred S. McChesney (editors). 2003. Property Rights: Cooperation, Conflict and Law. Princeton: Princeton University Press.

ANSW 4/2680. Colonial Secretary. Main Series of Letters Received 1826-1982.

ANSW 4/3660. Colonial Secretary. Main Series of Letters Received 1826-1982.

Bailey, M. 1992. "Approximate Optimality of Aboriginal Property Rights" Journal of Law and Economics, 35 (April), pp. 183-198.

Barzel, Yoram. 1989. Economic Analysis of Property Rights. New York: Cambridge University Press.

Barzel, Yoram. 2002. A Theory of the State: Economic Rights, Legal Rights and the Scope of the State. New York: Cambridge University Press.

Bassanezi, Maria Silvia C.B., Ana Silvia V. Scott, Carlos A.P. Bacellar and Oswaldo M. S. Truzzi. 2008. Atlas da Imigração Internacional em São Paulo - 1850-1950, São Paulo: Editora UNESP.

Bate, Weston. 1988. Victorian Gold Rushes. Melbourne: McPhee Gribble/Penguin Books.

Besley, Timothy. 1995. "Property Rights and Investment Incentives: Theory and Evidence from Ghana" Journal of Political Economy. 103, pp. 903-937.

Bogue, Allan G. 1963 (1st print 1958). "The lowa Claim Clubs: Symbol and Substance," in The Public Lands, Carstensen, Vernon ed. Madison, University of Wisconsin Press.

Braim, H. A. 1846. A history of NSW: from its settlement to the close of the year 1844. New York: Bently Press.

Briggs, H. E. 1934. "The Development and Decline of Open Range Ranching in the Northwest." Mississippi Valley Historical Review. 20, pp. 521-536.

Buchanan, James. M. and Gordon Tullock. 1965. The Calculus of Consent: Logical Foundations of Constitutional Democracy, University of Michigan Press.

Burroughs, Peter. 1967. Britain and Australia 1831-1855: A study in Imperial Relations and Crown Lands Administration. Oxford: Clarendon Press.

Burton, David H. 1997. Theodore Roosevelt, American Politician: An Assessment.

Madison: Fairleigh Dickinson University Press.

Butlin, Noel G. 1964. Investment in Australian economic development, 1861-1900, Melbourne, Cambridge University Press.

Butlin, Noel G. 1982. "Close encounters of the worst kind: modeling Aboriginal depopulation and resource competition, 1788-1850" Working Papers in Economic History, Number 8, Australian National University.

Carvalho, José Murilo de. 1988. Teatro de Sombras: A Política Imperial. São Paulo: Edições Vértice e IUPERJ.

Clune, D. and Griffith, G. 2006. Decision and Deliberation: the parliament of New South Wales, 18562003, Federation Press.

Coase, Ronald. 1959. "The Federal Communications Commission" The Journal of Law and Economics, 2 ( $N^{\circ}$ 1, October): pp. 1-40.

Coase, Ronald. 1960. "The Problem of Social Cost," The Journal of Law and Economics, 3, pp. 1-44.

Conover, Milton. 1923. The General Land Office: Its History, Activities, and Organization. Baltimore: The Johns Hopkins Press.

Costa, Emilia Viotti da. 1985. The Brazilian Empire: Myths \& Histories. Chicago: University of Chicago Press.

Coville, Frederick V. 1905. "A Report on Systems of Leasing Large Areas of Grazing Land" Report of the U.S. Public Lands Commission. Washington: Government Publications: pp. 26-61 
Crowley, F. 1980. Colonial Australia 1788 - 1840. Volume One. Melbourne: Nelson Press.

Curr, E. M. 2001 Recollections of Squatting in Victoria, then called the Port Phillip District (from 1841 to 1851), $2^{\text {nd }}$ edition. Melbourne: Melbourne University Press.

Dale, Edward Everett. 1960. The Range Cattle Industry: Ranching on the Great Plains from 1865 to 1925. Norman: University of Oklahoma Press.

Dean, Warren, 1971. "Latifundia and Land Policy in Nineteenth-Century Brazil," Hispanic-American History Review, Nov.:606-625.

Demsetz, Harold. 1967. "Towards a Theory of Property Rights." American Economic Review, 57:2, pp. 347-359.

Dennen, R.T. 1976. "Cattlemen's Associations and Property Rights in the American West," Explorations in Economic History, 13, pp. 423-436.

De Soto, Hernando. 2000. Mystery of Capital: Why Capitalism is Failing Outside the West \& Why the Key to Its Success is Right under Our Noses. New York, Basic Books.

Dingle, Anthony. 1984. The Victorians Settling. Melbourne: Fairfax, Syme and Weldon Associates.

Dunham, Harold H. 1963 (1st print. 1937). "Some Crucial Years of the General Land Office, 1875-1890," in The Public Lands, Carstensen, Vernon ed. Madison, University of Wisconsin Press.

Ellickson, Robert C. 1991. Order Without Law: How Neighbors Settle Disputes. Cambridge: Harvard University Press.

Ellis, David M. 1963 (1st print 1946). "Comment on 'The Railroad Land Grant Legend in American History Texts'," in The Public Lands, Carstensen, Vernon ed. Madison, University of Wisconsin Press.

Eggertsson, Thráinn. 1990. Economic Behavior and Institutions. New York: Cambridge University Press.

Field, Erica. 2002. "Entitled to Work: Urban Property Rights and Labor Supply in Peru." Working Paper, Princeton University. October.

Engerman, Stanley L. and Kenneth L.Sokoloff. 1997. "Factor Endowments, Institutions, and Differential Paths of Growth Among New World Economies: A View from Economic Historians of the United States," in How Latin America Fell Behind. Stephen Haber, ed., Stanford: Stanford University Press.

Ensminger, Jean. 1995. "Changing Property Rights: Reconciling Formal and Informal Rights to Land in Africa", 1997, The Frontiers of the New Institutional Economics, Academic Press.

Feder, Gershon and David Feeny. 1991. "Land Tenure and Property Rights: Theory and Implications for Development Policy" World Bank Economic Review. 3, pp. 135-53.

Fetherstonhaugh, Cuthbert. 1917. After Many Days. Melbourne: Cole Press

Foweraker, Joe. 1981. The Struggle for Land: A Political Economy of the Pioneer Frontier in Brazil from 1930 to the Present Day. Cambridge University Press.

Gates, Paul W. 1963 (1st print. 1936). "The Homestead Law in an Incongruous Land System," in The Public Lands, Carstensen, Vernon ed. Madison, University of Wisconsin Press.

Haddock, David D. 2003. "Force, Threat, Negotiation: The Private Enforcement of Rights," in Property Rights: Cooperation, Conflict and Law. Anderson, Terry L. and Fred S. McChesney eds, Princeton, Princeton University Press.

Hall, M. 1969. The Origins of Mass Immigration to Brazil, 1871-1914, New York: Columbia University, PhD thesis.

Halloway, Thomas. H. 1984. Immigrantes para o Café, Rio de Janeiro: Paz e Terra.

Hagedorn, Hermann. 1921. Roosevelt in the Bad Lands. Cambridge: The Riverside Press.

Hansen, Zeynep K. and Gary D. Libecap. 2004. "The allocation of property rights to land: US land policy and farm failure in the northern great plains" Explorations in Economic History. 41, 103-129.

Harris, Edwyna. 2008. 'The Persistence of Correlative Water Rights in colonial Australia: A Theoretical Contradiction.' Discussion Papers, Department of Economics, Monash University, No. 11/08.

Hawker, G. N. 1971. The parliament of New South Wales, 1856-1965, New South Wales Government Printer 
Henry, Robert S. 1963 (1st print. 1945). "The Railroad Land Grant Legend in American History Texts," in

The Public Lands, Carstensen, Vernon ed. Madison, University of Wisconsin Press.

Hughes, Jonathan and Louis P. Cain. American Economic History. Addison Wesley.

Imlah, Albert, H. 1950. 'The Terms of Trade of the United Kingdom, 1798-1913.' Journal of Economic History. 10:2, pp.170-194.

Kanazawa, Mark T. 1996. "Possession in Nine Points of the Law: The Political Economy of Early Land Disposal," Explorations in Economic History 33: 227-249.

Kociumbas, J. 1988. The Oxford History of Australia. Volume One. Melbourne: Oxford University Press.

La Croix, Sumner J. And James Roumasset. 1990. "The Evolution of Property Rights in NineteenthCentury Hawaii" The Journal of Economic History. 50:4 (Dec.), pp. 829-852.

Libecap, Gary D. 1978. "Economic Variables and the Development of the Law: The Case of Western Mineral Rights" Journal of Economic History. 38:2, pp. 399-458.

Libecap, Gary D. 1989. Contracting for Property Rights. New York: Cambridge University Press.

Libecap, Gary. 1981. Locking Up the Range: Federal Land Controls and Grazing. Cambridge: Ballinger Publishing Company.

Libecap Gary D. 2007. "The Assignment of Property Rights on the Western Frontier: Lessons for Contemporary Environmental and Resource Policy" Journal of Economic History. 67, 2 (May): 257291.

Libecap, Gary D. and Zeynep K. Hansen. 2004. "Small Farms, Externalities, and the Dust Bowl of the 1930s." Journal of Political Economy. 112, 3: (June): 665-694.

Libecap, Gary D. and Dean Lueck. 2009. "The Demarcation of Land and the Role of Coordinating Institutions," Working Paper University of California, Santa Barbara.

Lueck, Dean 2003. "First Possession as the Basis of Property" in Property Rights: Cooperation, Conflict and Law. Anderson, Terry L. and Fred S. McChesney, eds. Princeton, Princeton University Press.

Mattison, Ray H. 1950. "Roosevelt and the Stockmen's Association" North Dakota History. 17: 3 (July):177-209

McCabe, J. Terrence. 2004. Cattle Bring Us to Our Enemies: Turkana Ecology, Politics, and Raiding in a Disequilibrium System. Ann Arbor, University of Michigan Press.

McChesney, Fred S. 2003. "Government as Definer of Property Rights: Tragedy Exiting the Commons" in Property Rights: Cooperation, Conflict and Law. Anderson, Terry L. and Fred S. McChesney, eds. Princeton, Princeton University Press

McIntyre, S. 2004. A concise history of Australia, Melbourne: Cambridge University Press.

Mendelsohn, Robert. 1994. "Property rights and Tropical Deforestation" Oxford Economic Papers. 46, pp. 750-756.

Mercer, George. 1819-1838. George Mercer Papers. MS 13166, State Library of Victoria.

Migot-Adholla, Shem, Peter Hazell, Benoit Blarel and Frank Place. 1991. "Indigenous Land Rights System in Sub-Saharan Africa: A Constraint on Productivity?" World Bank Economic Review. 5, pp. 155-75.

Millis, R. 1992. Waterloo Creek: the Australia Day massacre of 1838, George Gipps and the British conquest of New South Wales, Sydney: McPhee and Gribble.

Morris, A. and Ranken, G. 1883. Report of Inquiry into the state of Public Lands and the operation of the Land Laws, New South Wales Legislative Assembly, Votes and Proceedings.

NBER. 2009. NBER Macrohistory: IV. Prices: Us.Wholesale Price of Cattle, Chicago 01/1858-12/1940. April 13, 2009 http://www.nber.org/databases/macrohistory/rectdata/04/m04007.dat

New South Wales. 1872/3. Select Committee on the Administration of Land Laws, $2^{\text {nd }}$ Progress Report, Legislative Assembly, Votes and Proceedings.

New South Wales. 1873/4. Select Committee on the Administration of Land Laws, 3rd Progress Report, Legislative Assembly, Votes and Proceedings 
Nimmo, J. 1884-1885. Report on the Internal Commerce of the United States. House Executive Document 7, Part 3, Serial 2295, $48^{\text {th }}$ Congress, Second Session.

Norlin, Kara.2003 "Political Corruption: Theory and Evidence from the Brazilian Experience," PhD Dissertation. University of Illinois.

North, Douglass C., John Joseph Wallis and Barry R. Weingast. 2009. Violence and Social Orders. New York: Cambridge University Press.

O'Neal, Bill. 1989. Cattlemen vs. Sheepherders: Five Decades of Violence in the West 1880-1920. Austin: Eakin Press.

Olson, Mancur. 1965. The Logic of Collective Action. Cambridge: Harvard University Press.

Osgood, Ernest Staples. 1929. The Day of the Cattleman. Chicago: University of Chicago Press.

Ostrom, Elinor. 1990. Governing the Commons: The Evolution of Institutions for Collective Action. New York: Cambridge University Press.

Osório Silva, Lígia 1996. Terras Devolutas e Latifúndio: Efeitos da Lei de 1850, Campinas, Editora da Unicamp.

Pelzer, L. 1936. The Cattlemen's Frontier. Glendale California: Arthur H. Clark Co.

Place, Frank and Peter Hazell. 1993. "Productivity Effects of Indigenous Land Tenure Systems in SubSaharan Africa" American Journal of Agricultural Economics 75, pp. 10-19.

Port Phillip Association. 1835-1836. Papers of the Port Phillip Association. MS 10258, State Library of Victoria.

Roberts, S. H. 1924. History of Australian Land Settlement. Melbourne: Macmillan Press.

Roberts, S. H. 1935. The Squatting Age in Australia 1835-1847. Melbourne: Melbourne University Press.

Robbins, Roy M. 1942. Our Landed Heritage. Princeton: Princeton University Press.

Sandoz, Mari. 1958. The Cattlemen. New York: Hastings House.

Sherow, James E. 2007. The Grasslands of the United States: An Environmental History. Santa Barbara: ABC-CLIO.

Smith, Frank E. 1968. "The Development of Public Land Policy," in Public Land Policy. Boulder: Colorado Associated University Press.

Smith, Henry E. 2000. "Semicommon Property Rights and Scattering in the Open Fields," Journal of Legal Studies, Vol. XXIX, N ${ }^{0} 1,1$, pp. 131-170.

Smith, Henry E. 2002 "Exclusion Versus Governance: Two Strategies for Delineating Property Rights." Journal of Legal Studies, Vol. XXXI, (June) S453-S487.

Stegner, Wallace E. 1954. Beyond the Hundredth Meridian: John Wesley Powell and the Second Opening of the West. New York: Penguin Press.

Terrell, John Upton. 1972. Land Grab: The Truth About the Winning of the West. New York: The Dial Press.

Umbeck, John, 1981, "Might Makes Right: A Theory of the Formation and Initial Distribution of Property Rights," Economic Inquiry, Vol. XIX, pp.38-59.

Vamplew, W. (ed.). 1987. Australians Historical Statistics. Melbourne: Fairfax, Syme, and Weldon.

Victoria. 1873. Board of Inquiry into proceedings in relation to certain land selection in the Wimmera District, Legislative Assembly, Votes and Proceedings.

Victoria. 1874. Crown Land Department Board of Inquiry, Legislative Assembly, Votes and Proceedings.

Walton Gary W. and Hugh Rockoff. 2004. History of the American Economy with Economic Applications. Dreyden Press.

Watson, Richard L., Jr. 1976. The Development of National Power: The United States, 1900-1919. Boston: Houghton Mifflin Company.

Weaver, John, C. 1996. "Beyond the Fatal Shore: Pastoral Squatting and the Occupation of Australia 1826 to 1852. American Historical Review, 101:4, pp. 981-1007. 
Weingast, Barry, 1997, The Political Foundations of Democracy and the Rule of Law. The American Political Science Review, 91:2, pp. 245-263.

Worster, Donald. 1994. An Unsettled Country: Changing Landscapes of the American West. Albuquerque: University of New Mexico Press.

Wright, R. 1992. A People's Council: a history of the Parliament of Victoria, 1856-1990, Melbourne: Oxford University Press. 


\section{Appendix 1}

In this appendix we show how the magnitude of the NPV associated with having secure private property affects the willingness of claimants to organize, lobby and fight for those rights. Let $\pi^{\mathrm{PP}}$ be the NPV a claimant receives if the land becomes private property. The claimant has some expectation of the probability that his side will win the dispute and get private property. This probability, $\theta$, is a function of the effort, $e$, his side puts towards lobbying, fighting, rent-seeking, persuading, etc. Thus $\theta(e)$ is the probability the claimants will be granted de jure and de facto private property.

Assuming that when one group is granted private property the other gets nothing, the expected NPV for a claimant is (let the superscript $\mathrm{i}=\mathrm{k}$, I represent capital or labor.

$E(N P V)^{k}=\theta\left(e^{i}\right) \pi^{P P, i}$

And the return to effort is: $\frac{\partial E\left(N P V^{i}\right)}{\partial e^{i}}=\frac{\partial \theta\left(e^{i}\right)}{\partial e^{i}} \pi^{P P, i} \geq 0$

The optimal amount of effort is given by:

$\operatorname{Max}_{e^{i}} \theta\left(e^{i}\right) \pi^{P P, i}-C^{i}\left(e^{i}\right)$

where $C^{i}(\cdot)$ is the cost of effort.

This maximization yields the standard result that in equilibrium the marginal benefit of effort equals the marginal cost of effort.

$\frac{\partial \theta\left(e^{i}\right)}{\partial e^{i}} \pi^{P P, i}=\frac{\partial C^{i}\left(e^{i}\right)}{\partial e^{i}}$

This expression can be used to determine the effect of a change of the value of land under private property on claimant $i$ 's optimal effort?

$$
\frac{\partial e^{i}}{\partial \pi^{P P, i}}=\frac{-\frac{\partial \theta\left(e^{i}\right)}{\partial \theta e^{i}}}{\pi^{P P, i} \frac{\partial^{2} \theta\left(e^{i}\right)}{\partial e^{i} \partial e^{i}}-\frac{\partial^{2} C^{i}\left(e^{i}\right)}{\partial e^{i} \partial e^{i}}}>0
$$

This is positive as the denominator is the second order condition of the maximization problem and is negative. This means that the greater the total value of the land under private property, that type of claimant will put in effort towards assuring those rights, which is what we set out to show.

One could argue, however, that to be more accurate the analysis should include the fact that when deciding the optimal amount of effort each group of claimants would take into account the other side's reactions in Cournot fashion. Repeating the exercise above but allowing each sides' perceived probability of getting the private property to be $\theta^{i}\left(e^{i}, e^{-i}\right)$ where -i refers to the other group, the comparative static result becomes:

$$
\frac{\partial e^{i}}{\partial \pi^{P P, i}}=\frac{-\frac{\partial \theta^{i}\left(e^{i}, e^{-i}\right)}{\partial e^{i}} * S O C^{-i}+\frac{\partial \theta^{-i}\left(e^{i}, e^{-i}\right)}{\partial e^{-i}} \pi^{P P, i} \frac{\partial^{2} \theta^{i}\left(e^{i}, e^{-i}\right)}{\partial e^{i} \partial e^{-i}}}{|\operatorname{det}|}
$$


Given that $\operatorname{SOC}^{i-}<0$ it can be shown that $|\operatorname{det}|>0$ and the final expression is positive if $\frac{\partial^{2} \theta^{i}\left(e^{i}, e^{-i}\right)}{\partial e^{i} \partial e^{-i}}$ is not very large. That is, unless the political equilibrium is particularly lopsided even with strategic interaction among the types of claimants, an increase in the value of the land with private property rights will lead to an increase in the effort of that group. 
Appendix 2: Extent of Selection in NSW and Victoria 1862-1880

\begin{tabular}{|l|l|l|l|l|}
\hline & $\begin{array}{l}\text { NSW } \\
\text { Number of } \\
\text { Year }\end{array}$ & $\begin{array}{l}\text { NSW } \\
\text { Number of selections } \\
\text { (acres) }\end{array}$ & $\begin{array}{l}\text { (2) } \\
\text { Victoria } \\
\text { Number of selections }\end{array}$ & $\begin{array}{l}\text { Victoria } \\
\text { Number of selections } \\
\text { (acres) }\end{array}$ \\
\hline 1862 & 2449 & 207675 & & \\
\hline 1863 & 1630 & 121493 & & \\
\hline 1864 & 1166 & 86475 & & \\
\hline 1865 & 1050 & 70432 & & \\
\hline 1866 & 2022 & 196043 & & \\
\hline 1867 & 1568 & 140511 & & \\
\hline 1868 & 1584 & 129634 & & \\
\hline 1869 & 2361 & 227992 & 3148 & \\
\hline 1870 & 2105 & 184287 & 5248 & 487256 \\
\hline 1871 & 2117 & 195043 & 9179 & 797176 \\
\hline 1872 & 3019 & 346585 & 8144 & 1063066 \\
\hline 1873 & 4761 & 619386 & 11071 & 1831698 \\
\hline 1874 & 4844 & 693489 & 7091 & 183520 \\
\hline 1875 & 4632 & 738523 & 6482 & 1040356 \\
\hline 1876 & 3994 & 933713 & 7017 & 1126492 \\
\hline 1877 & 3578 & 715440 & 9058 & 1915129 \\
\hline 1878 & 3842 & 703902 & 6688 & \\
\hline 1879 & 2625 & 468121 & 5213 & \\
\hline 1880 & 2867 & 566774 & & \\
\hline & & & & \\
\hline
\end{tabular}

${ }^{a}$ Data compiled from Votes and Proceedings of the Legislative Assembly NSW, 1883

${ }^{b}$ Data compiled from Annual Reports of Department of Lands and Surveys, Victorian Parliamentary Papers, 1870-1880. 
Appendix 3: Total voided selections per annum, NSW and Victoria, 1862-1883

\begin{tabular}{|c|c|c|c|c|}
\hline Year & $\begin{array}{l}\text { NSW } \\
\text { Number of } \\
\text { selections }^{\text {a }}\end{array}$ & $\begin{array}{l}\text { NSW } \\
\text { Voided } \\
\text { selections (\%) }\end{array}$ & $\begin{array}{l}\text { Victoria } \\
\text { Number of } \\
\text { selections }^{b}\end{array}$ & $\begin{array}{l}\text { Victoria } \\
\text { Voided selections } \\
(\%)^{\mathbf{b}}\end{array}$ \\
\hline 1863 & 2449 & 16.90 & & \\
\hline 1864 & 1630 & 10.74 & & \\
\hline 1865 & 1166 & 18.61 & & \\
\hline 1866 & 1050 & 40.48 & & \\
\hline 1867 & 2022 & 13.01 & & \\
\hline 1868 & 1568 & 15.37 & & \\
\hline 1869 & 1584 & 26.89 & & \\
\hline 1870 & 2361 & 14.65 & & \\
\hline 1871 & 2105 & 18.19 & & \\
\hline 1872 & 2117 & 36.61 & & \\
\hline 1873 & 3019 & 48.33 & & \\
\hline 1874 & 4761 & 39.68 & 9578 & 0.02 \\
\hline 1875 & 4844 & 48.27 & 6320 & 0.16 \\
\hline 1876 & 4632 & 45.88 & 5785 & 1.33 \\
\hline 1877 & 3994 & 44.79 & 6240 & 3.56 \\
\hline 1878 & 3578 & 50.45 & 7524 & 3.62 \\
\hline 1879 & 3842 & 27.38 & 5726 & 4.96 \\
\hline 1880 & 2625 & 53.75 & 4036 & 8.77 \\
\hline 1881 & 2867 & 66.93 & 3110 & 2.38 \\
\hline 1882 & 4983 & 19.93 & 4383 & 1.32 \\
\hline 1883 & 5158 & 62.43 & 4453 & 1.15 \\
\hline
\end{tabular}

a Data from Morris and Ranken, 1883.

${ }^{\mathrm{b}}$ Data compiled from Annual Reports of Department of Lands and Surveys, Victorian Parliamentary Papers, 1874-1883. 
Appendix 4: Number of selections transferred and forfeited, NSW 1862-1883

\begin{tabular}{|l|l|l|l|l|l|}
\hline Year & $\begin{array}{l}\text { Number of } \\
\text { selections }\end{array}$ & $\begin{array}{l}\text { Number } \\
\text { Transferred }\end{array}$ & $\begin{array}{l}\text { Transferred } \\
\text { (\%) }\end{array}$ & $\begin{array}{l}\text { Number } \\
\text { Forfeited }\end{array}$ & $\begin{array}{l}\text { Forfeited } \\
\text { (\%) }\end{array}$ \\
\hline 1862 & 2449 & 1240 & 50.63 & 162 & 6.61 \\
\hline 1863 & 1630 & 996 & 61.10 & 178 & 10.92 \\
\hline 1864 & 1166 & 729 & 62.52 & 258 & 22.13 \\
\hline 1865 & 1050 & 645 & 61.43 & 250 & 23.81 \\
\hline 1866 & 2022 & 1298 & 64.19 & 629 & 31.11 \\
\hline 1867 & 1568 & 1020 & 65.05 & 244 & 15.56 \\
\hline 1868 & 1584 & 1031 & 65.09 & 207 & 13.07 \\
\hline 1869 & 2361 & 1510 & 63.96 & 245 & 10.38 \\
\hline 1870 & 2105 & 1331 & 63.23 & 209 & 9.93 \\
\hline 1871 & 2117 & 1279 & 60.42 & 221 & 10.44 \\
\hline 1872 & 3019 & 1829 & 60.58 & 741 & 24.54 \\
\hline 1873 & 4761 & 2777 & 58.33 & 1089 & 22.87 \\
\hline 1874 & 4844 & 2779 & 57.37 & 889 & 18.35 \\
\hline 1875 & 4632 & 2661 & 57.45 & 714 & 15.41 \\
\hline 1876 & 3994 & 2556 & 64.00 & 250 & 6.26 \\
\hline 1877 & 3578 & 2128 & 59.47 & 209 & 5.84 \\
\hline 1878 & 3842 & 2011 & 52.34 & 268 & 6.98 \\
\hline 1879 & 2625 & 1090 & 41.52 & 129 & 4.91 \\
\hline 1880 & 2867 & 354 & 12.35 & 43 & 1.50 \\
\hline 1881 & 4983 & 23 & 0.46 & 13 & 0.26 \\
\hline 1882 & 5158 & 3 & 0.06 & 11 & 0.21 \\
\hline
\end{tabular}

Source: Adapted from Morris and Ranken (1883) 